\title{
Rockfall and vulnerability of mountaineers on the west face of the Aiguille du Goûter (classic route up Mont Blanc, France), an interdisciplinary study
}

Jacques Mourey ${ }^{1,2}$, Pascal Lacroix ${ }^{3}$, Pierre-Allain Duvillard ${ }^{1,4}$, Guilhem Marsy 1,5,6, Marco Marcer ${ }^{7}$,

5 Ludovic Ravanel ${ }^{1}$, Emmanuel Malet ${ }^{1}$

${ }^{1}$ EDYTEM, Savoie Mont-Blanc University, CNRS, 73000 Chambéry, France.

${ }^{2}$ Interdisciplinary Centre for Mountain Research, University of Lausanne, Ch. de l'Institut 18, CH-1967 Bramois, Switzerland

${ }^{3}$ ISTerre, IRD-CNRS-OSUG, Grenoble Alpes University, 38400 Saint-Martin-d'Hères, France.

${ }^{4}$ Styx 4D, 73370 Le Bourget du Lac, France.

$10 \quad{ }^{5}$ LISTIC, Savoie Mont-Blanc University, Polytech Annecy-Chambéry, France.

${ }^{6}$ TENEVIA, 38240 Meylan, France.

${ }^{7}$ PACTE, Grenoble Alpes University, Alpine Geography institute, CNRS, 38041 Grenoble, France.

Correspondence to: Jacques Mourey (jacques.mourey@unil.ch)

Abstract. In high alpine environments, climate change leads to an increase in rockfall destabilizations. They represent a threat

15 for sports and tourism activities in high mountain and especially for mountaineering. This danger of rockfall is particularly important on the classic route up Mont Blanc (4,809 m a.s.l., Mont Blanc massif, France), on the west face of the Aiguille du Goûter (3,863 m a.s.l.), and is responsible for at least $29 \%$ of the accidents that occur in this sector. Despite the intensity of the geomorphological processes at work and the vulnerability of climbers, few scientific studies have been carried out on the occurrence of rockfalls and their triggering factors in the Goûter area. Based on a multi-method monitoring system (5 seismic sensors, an automatic digital camera, 3 subsurface temperature sensors, a pyroelectric sensor, a high-resolution topographical survey, 2 weather stations and a rain gauge) the objective of our study is therefore to quantitatively document the occurrence of rockfalls and their triggering factors in the Grand Couloir du Goûter in order to better assess the vulnerability of mountaineers in this sector. Our results show that in the high-Alpine and permafrost-affected Aiguille du Goûter west face, rockfalls are mostly frequent during the snowmelt period which favors the action of thermo-mechanical processes linked to the infiltration of liquid water into the cracks of the rock. During periods when the couloir is completely clear of snow, rockfalls are 2.5 times less frequent, and the thermo-mechanical processes involved in the rockfall triggering are limited by the absence of moisture in the ground. These results also show that climbers' awareness of the risk of rockfalls remains limited. What's more, they do not adapt - or only slightly - their behavior to this risk, despite a particularly high accident rate. Important work on prevention and dissemination of the knowledge here acquired (newsletters, training for professionals and amateurs, awareness campaigns) among mountaineers is therefore still really necessary. 


\section{Introduction}

Climate change leads to deep changes in high alpine environments (Beniston et al. 2018; IPCC, 2019) and, in particular, to rock faces increasingly destabilized (Harris et al. 2001; Gruber and Haeberli, 2007; Ravanel and Deline, 2010; Allen and Huggel, 2013; Ravanel et al. 2017). These changes represent a threat to sports and tourism activities in high mountains, some with a high economic and heritage value such as mountaineering (Ritter et al. 2011; Temme, 2015; Probstl-Haider et al. 2016; Purdie and Kerr, 2018; Mourey et al. 2019; Mourey et al. 2020), recently inscribed by UNESCO on the Representative List of the Intangible Cultural Heritage of Humanity (Debarbieux, 2020).

Despite a growing body of scientific literature, several international entities such as the World Meteorological Organization (WMO), the Intergovernmental Panel on Climate Change (IPCC) and the Mountain Research Initiative (MRI) agreed on the profound lack of knowledge on the vulnerability to climate change to climate change of socio-economic activities in mountains. Echoing this observation, a review of studies on adaptation actions in glaciated mountain areas (McDowell et al. 2019) showed that the majority of adaptation strategies are implemented in direct reaction to stimuli and do not respond to well thought-out plans, based on scientific knowledge and taking into account all the interacting socio-economic factors as well as the future effects of climate change. This results in a significant lack of medium- and long-term efficiency of these adaptation strategies. In this context, this article presents an interdisciplinary study whose objective is to better assess the vulnerability of mountaineers climbing the classic route up Mont Blanc (4,809 m a.s.l., Mont Blanc massif - MBM - France), the highest summit in the European Alps. This route is undoubtedly one of the most popular in the world, but its climbing parameters (technical difficulty, level of exposure to objective dangers and optimal period for making an ascent) have significantly changed due to the effects of climate change (Mourey et al. 2019). This evolution is mostly due to an increasing number of rockfalls in the west face of the Aiguille du Goûter (3,863 m a.s.1.) including the crossing of the Grand Couloir du Goûter and the ascent of the Goûter rock ridge ("arête du Goûter") leading to the Goûter refuge located at 3,835 m a.s.l. This sector is probably the most accident-prone area in the Alps for mountaineers, with an average of 3.7 fatal accidents and 8.5 injuries per summer season since 1990 (Mourey et al. 2018), hence its reputation in the media as the "couloir of death". Rockfalls directly explain at least $29 \%$ of the accidents and are partly involved in the accidents due to a fall, which account for $50 \%$ of the accidents (Mourey et al. 2018).

Despite the intensity of the geomorphological processes at work and the vulnerability of climbers, few scientific studies have been carried out on the occurrence of rockfalls and their triggering factors in the Goûter area. Based on 42 days of in situ visual observations during the day ( 8 am -6 pm) in the summer 2011, Alpes-Ingé (2012) quantified the rockfall frequency. However, this study has many limitations: destabilisations were not measured over the whole season nor during periods of bad weather

60 (rain, fog, thunderstorms), nor at the end of the day, night and early morning. Lemarechal (2011) proposed, on the basis of a trajectography study, various possibilities for securing the crossing of the couloir (purging of the face, signalling, installation of block nets, protection of the crossing with a concrete structure, installation of a footbridge, etc.). However, until now, no 
continuous observation of rockfalls was available to better characterize their occurrence and their triggering factors (temperature, rainfall, snow cover, human activity).

65 The objective of our study is therefore to quantitatively document the occurrence of rockfalls and their triggering factors in the Grand Couloir du Goûter which is located in context of permafrost according to Magnin et al. (2015). Permafrost refers to any lithospheric materials with temperature remaining below $0^{\circ} \mathrm{C}$ for at least two consecutive years (Dobinski, 2011). The acquired knowledge should then help the development of adaptive behaviours among climbers and, as a result, reduce the number of accidents in this area. To meet this objective, an innovative interdisciplinary monitoring system was set up in 2016 and became fully operational in 2019. Thanks to seven different methodologies, it led to the measurement of rockfalls frequency and intensity, the evolution of the snow cover in the couloir, the temperature of the rock, the air temperature, the rainfall and the climber traffic in the couloir. The comparison between rockfall occurrences and environmental parameters should enable us to identify the most favourable conditions for rockfall, while the analysis of the attendance levels should allow to better evaluate their vulnerability in this particularly accident-prone sector.

\section{Rockfall triggering factors in high alpine environments}

In context of permafrost in high alpine environments, rockfall occurrence is preconditioned by the lithological and structural characteristics of the rock (especially its degree of fracturing) and the topography (Krautblatter et al. 2013; Mc Coll and Draebing, 2019). Then, climatic and meteorological factors such as the presence/absence of snow, precipitation and air temperature will initiate thermo-mechanical processes involved in the rockfall triggering (Fig. 1).

80 In permafrost-affected rockwalls, thermal processes are characterized by heat flux between the surface and the depth of the rock masses by conduction along a temperature gradient in intact rock (McColl and Dreabing, 2019), and/or by advection through percolation of water along fractures (Gruber and Haeberli, 2007; McColl and Dreabing, 2019), and/or by convection due to the air and water circulation along the fractures (Moores et al. 2011; McColl and Dreabing, 2019). The action of these thermal processes in triggering rockfalls occurs on several time scales (daily, seasonnal, annual). Gruber and Haeberli (2007) consider the degree of fracturing of the rock, the presence of snow/ice on the surface and the availability of liquid water as the key controlling factors of these heat fluxes. The degree of fracturation affects the ability of water and air to infiltrate into the rock and the amount of interstitial ice that may be present at depth - that can impede fluid flow. The presence of snow/ice at the surface partly controls the temperature of the rock (Magnin et al. 2015) and the amount of liquid water available in the rock fractures which also affects advective heat transfers. The opening of cracks during melting periods, i.e. when the amount

90 of liquid water is the highest, has been observed by several authors like Wegmann and Gudmundsson (1999), Krautblatter ( 2010), Hasler et al. (2012) or Weber et al. (2017). According to McColl and Draebing (2019), these thermal processes tend to be the most efficient in triggering rockfalls in high alpine mountains, ahead of the mechanical processes presented below. Conditioned by these thermal processes and meteorological conditions, three mechanical processes - possibly combined - are involved in the rockfall triggering (Fig. 1). (i) The increase of hydrostatic pressure in cracks (Krautblatter et al. 2013) due to 
the infiltration of liquid water, either from melting snow or surface ice or from liquid precipitation. Liquid precipitation is the phenomenon that brings the most moisture to the ground surface (Sass, 2005a). (ii) The flow/streaming of water at the surface of the slope can mobilize small debris on the rock surface (flow force). Krautblatter and Dikau (2007) and Krautblatter and Moser (2009) define this type of event as 'secondary rockfall'. (iii) The increase in cryoclastic pressure. When the air temperature drops below the melting point, the presence of water in the cracks of the rock will promote an increase in cryostatic pressure. A freezing phase is characterised by a volumetric expansion of water (+9\%). The water being confined in a limited space, the increase in volume leads to an increase in cryostatic pressure up to $207 \mathrm{MPa}$ (Matsuoka and Murton, 2008), making the opening of cracks and the rock fracturing possible. The repetition of many freeze-thaw cycles will lead to the widening of cracks and the fracturing of the rock (frost weathering). The efficiency of freeze-thaw cycles in triggering rockfalls is mainly related to the amount of water in the ground (Strass, 2005), the fracture density and the frequency of the cycles (Mamot et al.

105 2018). During the freezing phase, cementing of the frozen material generally occurs, which is rather unfavourable for the initiation of rockfalls. Conversely, the thawing phase is characterised by the warming/melting of the ice, thus a loss of volume and a settling of the thawed material, accompanied by a de-cementing and the infiltration of liquid water into the rock fractures, favouring rockfalls. Matsuoka (1990) and Seto (2010) differentiate between freeze-thaw cycles (FTC), defined by a drop in rock temperature below $0^{\circ} \mathrm{C}$ followed by an increase above $0^{\circ} \mathrm{C}$, and effective freeze-thaw cycles (EFTC) defined by a drop

110 in rock temperature below $-2^{\circ} \mathrm{C}$ followed by an increase above $2^{\circ} \mathrm{C}$. In addition, Matsuoka (2008) indicates that crack opening in relation to cryostatic pressure occurs on three different time scales: (i) small openings related to daily freeze-thaw cycles, (ii) slightly larger openings during seasonal refreezing, and (iii) even larger but punctual openings related to meltwater refreezing.

In a steep permafrost slope such as the west face of the Aiguille du Goûter, all these thermo-mechanical processes can be 115 operating (Fig. 1) and, depending on the conditions, can favour the stability or, on the contrary, slope instability. Draebing et al. (2014) proposed a conceptual model to understand these interactions and their role in rockfall triggering in permafrost context. Two periods particularly conducive to the occurrence of rock destabilization are identified: early summer and autumn. In early summer, the infiltration of liquid water from melting snow accelerates the deepening of the active layer - the subsurface horizon that thaws during the summer period - along the cracks (Gruber and Haeberli, 2007) and causes the melting of the ice in the cracks (Hasler et al. 2011). As a result, the shear strength of the rock is reduced by the thawing of the active layer while hydrostatic pressure increases, favouring the initiation of rockfalls (McColl and Draebing, 2019). In autumn, the cooling of the rock by conduction, possibly amplified by convection (Moore et al., 2011), leads to the freezing of water and the increase of cryostatic pressure. Ravanel et al. 2017 also identify autumn as a favourable period for the occurrence of large-scale destabilisations $\left(\mathrm{V}>10,000 \mathrm{~m}^{3}\right)$, as deep warming of the terrain reaches its maximum at this time of the year.

125 Based on the literature presented above, one of the interests of our study will be to better characterize and quantify the role of meteorological and climatic forcing in the triggering of rockfalls occurring in the Grand Couloir du Goûter. 


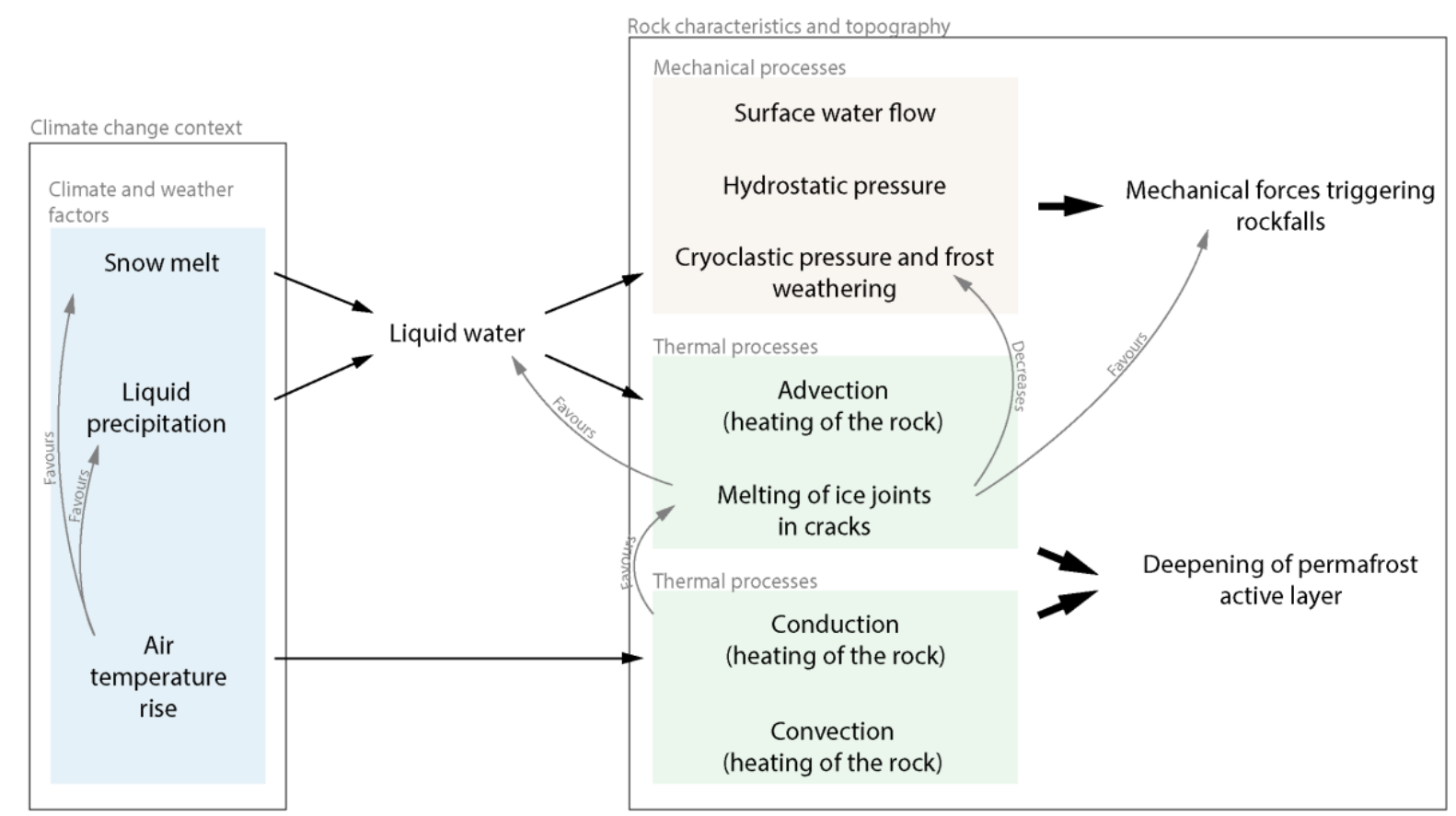

Figure 1: Mechanical and thermal processes at the origin of rockfalls in high Alpine environments.

\section{Study site}

\section{3.1 The Mont Blanc massif, the birthplace of mountaineering}

The MBM is located in the north-western Alps, between Switzerland, Italy and France (Fig. 2). It covers $\sim 550 \mathrm{~km}^{2}$. About $30 \%$ of its surface is covered with ice (Gardent et al. 2014) with 121 glaciers (Paul et al. 2020) including the Mer de Glace, the largest glacier in the French Alps with an area of $30 \mathrm{~km}^{2} .28$ summits exceed 4,000 m a.s.l., including the Mont Blanc $(4,809 \mathrm{~m}$ a.s.l.), the highest summit in the massif and of the European Alps. The conquest of these summits, and particularly

135 the Mont Blanc, led to the birth of mountaineering at the end of the $18^{\text {th }}$ century (Hoibian and Defrance, 2002). Nowadays, mountaineering is an emblematic sport and an important social/economic activity in the massif, attracting tens of thousands of climbers every year. In 2017, 51,687 overnight stays were recorded in the 16 high mountain refuges of the French and Swiss sides of the massif (data: French Federation of Alpine Clubs and Swiss Alpine Club). In 2019, on the initiative of Chamonix (France) and Courmayeur (Italy), mountaineering was inscribed by UNESCO on the Representative List of the Intangible

140 Cultural Heritage of Humanity (Debarbieux, 2020).

\subsection{The Grand Couloir du Goûter, on the classic route up Mont Blanc}

The Grand Couloir du Goûter (Fig. 2) is located on the west face of the Aiguille du Goûter (3863 m a.s.l.), itself located in the south-western part of the MBM. The classic route up Mont Blanc crosses this couloir in its lower part, at an altitude of 
3,270 $\mathrm{m}$ a.s.l. over an horizontal distance of about $70 \mathrm{~m}$. The route then follows the left bank of the couloir over an elevation

gain of almost $500 \mathrm{~m}$ up to its summit at 3,817 $\mathrm{m}$ a.s.l. This sector is one of the most difficult part of the route because of its steepness (slope angle between 45 and $60^{\circ}$ ), and also the most dangerous because of rockfalls whose frequency and volume have increased during recent decades (Mourey et al. 2019). According to Alpes-Ingé (2012), a rockfall occurs on average every 28 minutes in summertime. In 2015, due to two heat waves during which rockfalls were particularly frequent, climbing the couloir was strongly discouraged and the Goûter refuge (located on the summit ridge of the Aiguille du Goûter, Fig 2) was closed by prefectural decree from July $15^{\text {th }}$ to $31^{\text {st }}$ and then from August $6^{\text {th }}$ to $19^{\text {th }}$, corresponding to $23 \%$ of the traditional opening period of the refuge. These closures resulted in a drop in the number of overnight stays of $17 \%$ for the Goûter refuge and $39 \%$ for the Tête Rousse refuge (located at the base of the face) compared to the average for the three previous years. The topographical and geological characteristics of the Grand Couloir du Goûter are particularly favourable to the triggering of rockfalls. Indeed, the sector is formed of highly fractured gneiss and micaschists (Mennessier, 1977; Alpes-Ingé, 2012), with a slope angle between 45 and $60^{\circ}$ over an altitude difference of $700 \mathrm{~m}$.

\section{Methodologies}

Several factors potentially responsible for the triggering of rockfalls were studied and quantified in parallel with the traffic on the route through a multi-parameter and multi-method monitoring system composed of (Fig. 2): (i) 5 seismic sensors to detect the impacts of rockfalls, day and night, independently of weather conditions, and to estimate their intensity ; (ii) an automatic digital camera to monitor the evolution of snow-covered surfaces in the couloir; (iii) 3 subsurface temperature sensors installed $10 \mathrm{~cm}$ deep in the rock to analyse the presence/absence of the permafrost and its thermal regime; (iv) a pyroelectric sensor to record the number, time and direction of climbers crossing the couloir; (v) a high-resolution topographical survey by terrestrial laser scanning to define the topography of the couloir ; (vi) 2 weather stations measuring air temperature, one near the Tête Rousse glacier (3,126 m a.s.l.) and the other close to the Goûter refuge (3,817 m a.s.1.); and (vii) a rain gauge, positioned at

165 the base of the couloir (3,270 $\mathrm{m}$ a.s.l.) and measuring liquid rainfalls. In this section, the main methods used are detailed in order to clarify their interests and limitations. 


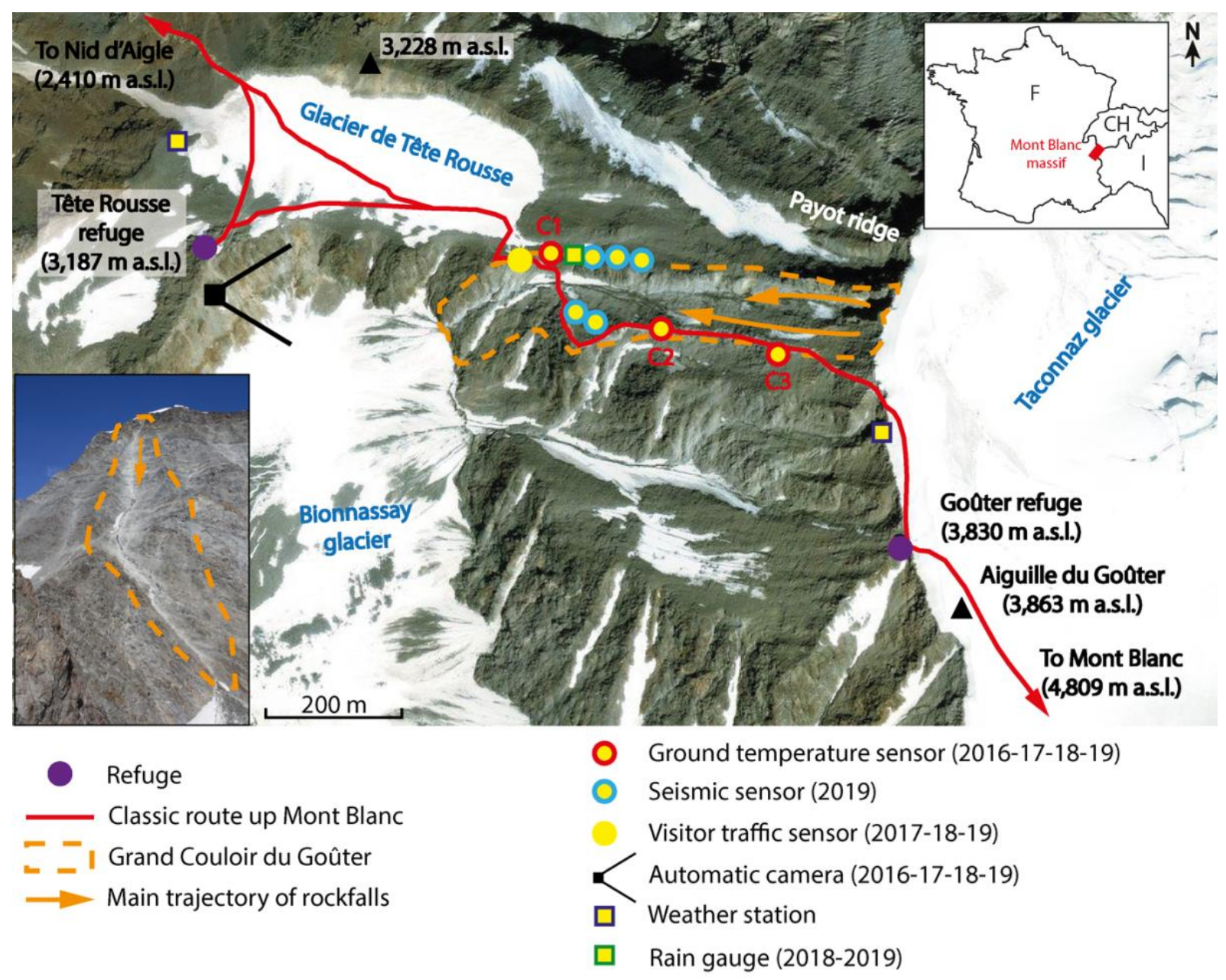

Figure 2: Study site and interdisciplinary monitoring system of the Grand Couloir du Goûter. The years indicated correspond to the presence of the different sensors (aerial photography from (C) Microsoft, 2019; Ground picture: J Mourey, 2019).

\subsection{Detection and characterization of rockfalls}

5 autonomous seismic sensors (Zland3C nodes), short period with a sampling frequency of $250 \mathrm{~Hz}$, installed on both sides of the couloir (Fig. 2) from the 29/06 to the 04/09/2019 (68 days) were used for the detection of the seismic signals generated by rockfalls and to characterize their energy. The detection was carried out following the method developed by Helmstetter and Garambois (2010), by isolating peaks in the spectrograms stacked in the frequency band [130] Hz, with amplitudes greater than 4 times the noise level (calculated over $30 \mathrm{~s}$ at the onset of the records). All the peaks separated by less than 30s are considered to be part of the same event. This method makes it possible to isolate a large number of signals, not all of which are rockfalls (earthquakes, anthropogenic noise including helicopters). A visual expert analysis was then used to classify these signals and identify those due to rockfalls. The visual expertise was trained by field comparison done 2 times during 2 hours, once in July and once in August 2019. We decided to keep only the largest signals, i.e. when rockfall origin was sure. This 
180 corresponds to about only $10 \%$ of the detected signals. Finally, the most energetic peaks of each signal were located by a beam-forming method (Lacroix and Helmstetter, 2011). The signals for which the majority of peaks were located in the couloir (calculated according to Lacroix and Helmstetter, 2011) were kept (Fig. 3). The others were considered as coming from outside the couloir. This strategy makes it possible to obtain an inventory of rockfalls in the couloir, precisely located in time and space, with their energy.

185 Quantifying rockfalls volumes from seismic signals is the subject of many studies (Dietze et al. 2017; Hibert et al. 2017; Le Roy et al. 2019). Volumes can be derived from the characteristics of the seismic signal (duration, energy, amplitude) and are a function of the distance to the source, the type of ground impacted, the drop height, etc. Quantification of volumes requires calibration of the seismic data with an independent source (comparison of DTMs acquired two years apart, for example for Durand et al. 2018). Such a calibration was not possible here, as only one DTM was acquired by LiDAR (see § 3.2). However,

190 as the impact sources are all located at the center of the seismic network, the signal energy can be considered as a first relative indicator of the volume of rockfall. It should also be noted that this volume will tend to be underestimated when there is snow in the corridor, which absorbs the impacts.

According to Dietze et al. 2017, seismic sensors positioned $200 \mathrm{~m}$ away from the impact zone of rockfalls can detect events with a minimum volume of $0.05 \mathrm{~m}^{3}$. In our study, the sensors are positioned particularly close to the impact zone (approx. 50

$195 \mathrm{~m}$ ) and are therefore certainly able to detect volumes smaller than $0.05 \mathrm{~m}^{3}$ but not necessarily exhaustively. Rockfalls signals with low peaks, related either to small rocks/blocks that slide down without impacting the ground, or snow-damped rocks/blocks are thus not necessarily recorded. The results presented in the following sections therefore underestimate the amount of rockfalls, especially the smaller ones. The major interest of this data acquisition method is its ability to detect rockfalls continuously, at any time (even at night), and in any weather conditions. 
https://doi.org/10.5194/nhess-2021-128

Preprint. Discussion started: 27 April 2021

(c) Author(s) 2021. CC BY 4.0 License.

Discussions

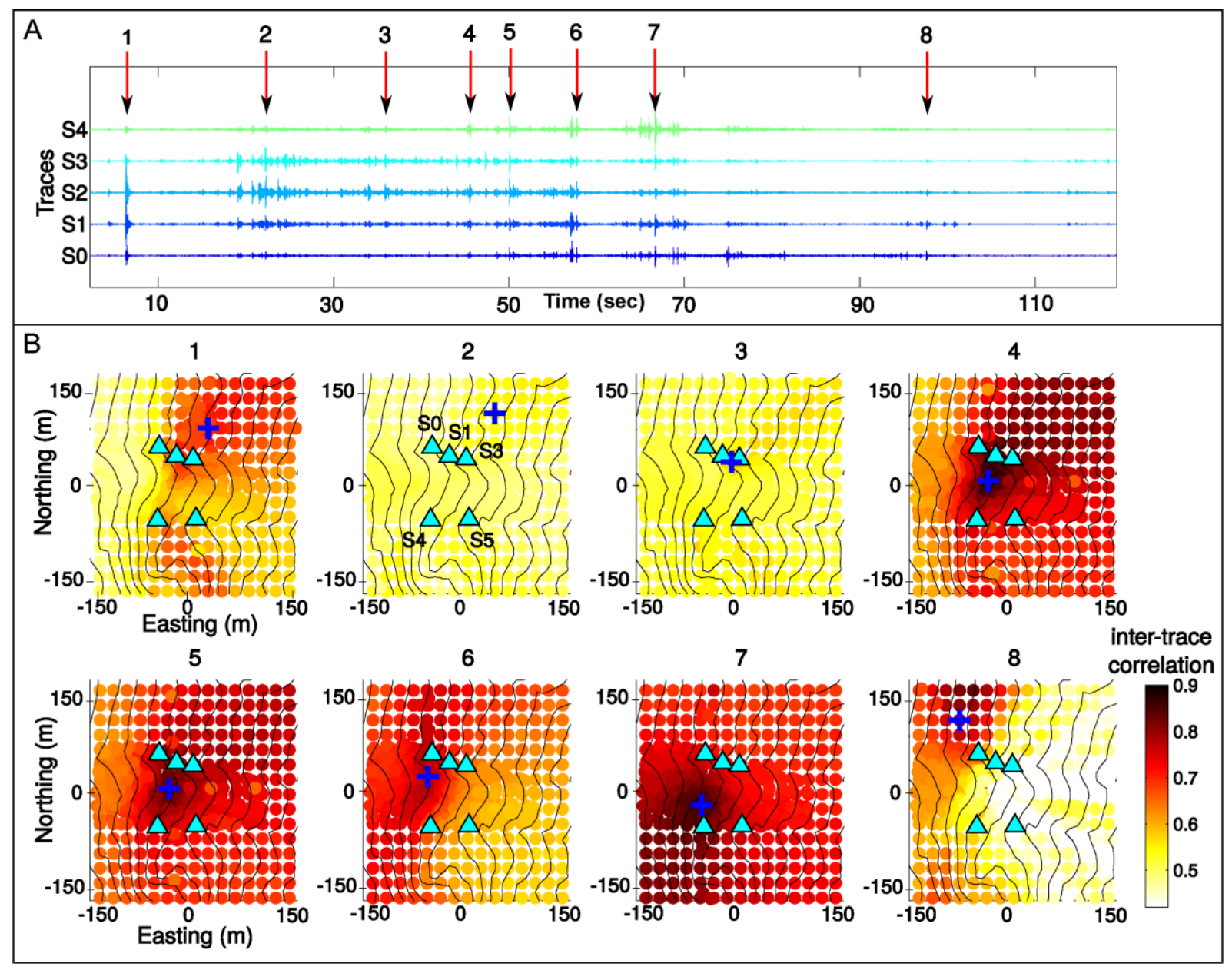

Figure 3: A. Seismic waveforms of a rockfall occurring on the $2^{\text {nd }}$ of August 2019, recorded by the 5 sensors (noted S1 to S5 and located with blue triangles on the maps of subplots $B$ ). The main impacts (noted 1 to 8 ) are automatically located by the beamforming method. B. Spatial distribution of the inter-trace correlation for each of the 8 impacts. The optimum location is indicated with a blue cross. The elevation iso-contours are displayed every $25 \mathrm{~m}$.

\subsection{Photographic monitoring of the snow cover}

In order to study the evolution of the snowpack, an automatic camera was installed in June 2016 (Fig. 2). It takes 4 photos per day of the couloir over the whole summer period. The photos were processed in 3 steps: i) manual selection of the images suitable for studying snow (absence of clouds, fog, or shadows); ii) on each photo, the pixels associated with snow are detected and isolated. Only the blue channel is used (Fedorov et al. 2016) in which the histogram of the pixels presents two color peaks whose thresholding allows to efficiently segment the snow pixels from the snow-free pixels; this segmentation is done automatically using the Isodata algorithm (Ridler and Calvard, 1978); iii) these same pixels are then converted into an area in $\mathrm{m}^{3}$ by a monoplotting technique: based on the intrinsic (sensor size, focal length, optical center, distortion) and extrinsic (position and orientation in space) parameters of the camera (Hartley and Zisserman, 2003), a ray-tracing on a DTM - acquired 
in 2016 by Terrestrial Laser Scanning (TLS, LiDAR method for Light Detection And Ranging) using an ILRIS LR Optech,

from the surroundings of the Tête Rousse refuge - is carried out for each pixel of the photos, which are then converted into a metric surface (Flöry et al. 2020).

\subsection{Characterisation and modelling of the permafrost thermal state}

Continuously measuring the rock surface temperature (RST) for at least one full year (Gruber et al., 2004; Magnin et al. 2015) allows to verify the presence/absence of permafrost. 3 Geoprecision PT100.0 sensors (C1, 3,345 m a.s.1.; C2, 3,460 m a.s.1.; C3, 3,665 m a.s.l., on Fig. 2) with M-Log5W loggers (resolution: $0.01^{\circ} \mathrm{C}$, accuracy $+/-0.1^{\circ} \mathrm{C}$ with temperature recorded every 3 hours) were installed out of the sunlight, $10 \mathrm{~cm}$ deep in the rock in July 2016. To ensure that there is no influence of the air temperature, a silicone seal ensures that there is no air circulation between the outside air and the hole in which the sensor is installed (Ravanel et al. 2017). The acquired data allow the analysis of the annual thermal regime of the subsurface and attest the presence/absence of permafrost.

RST were also used to simulate the evolution of permafrost temperature at depth by a heat conduction model (Hipp et al. 2014). Time series of daily RST for sensor C3 were reconstructed by fitting a linear regression model between the RST measured by the sensor and the local air temperature long-time records (data from Météo France). We tested the fit of the model with air temperature records at Chamonix (1,042 m a.s.l.) and at the Aiguille du Midi (3,842 $\mathrm{m}$ a.s.l.). The best correlation between the measured daily RST and the daily air temperature was obtained with the Aiguille du Midi time series (Correlation coefficient of 0.9 versus 0.8 for the Chamonix time series). We therefore used the air temperature time series of the Aiguille du Midi for the period August 2003 to May 2020. This time series was then used to force a MATLAB diffusive transient thermal model, the CRYOGRID2 model (Westerman et al. 2013), based on a 1D non-linear diffusion equation taking into account rock properties, air content, water/ice content and associated thawing/freezing processes through latent heat consumption and release. The ground properties (air content, water/ice content) were deduced from geotechnical surveys at a depth of 4 to $7 \mathrm{~m}$, carried out in 2006 for the construction of the Goûter refuge.

\subsection{Continuous monitoring of climbers' traffic}

The number of climbers following the route was continuously monitored from the June $29^{\text {th }}$ to September $15^{\text {th }}$ in 2017,2018 and 2019 using a pyroelectric sensor (Fig. 2; Mourey and Ravanel, 2017) installed on the side of the "trail" before the section that crosses the couloir. This type of sensor combines passive infrared technology with a high-precision lens to detect the heat emitted by the human body and determine the direction of travel, with the crucial advantage of not being influenced by weather conditions. Thus, the number of visitors that passed the sensor and their direction of travel were recorded continuously, with a value produced in 15-minute sequences. This means that the number of climbers and their direction of travel were known for each quarter of an hour. The sensor's margin of error was quantified by performing at least three manual counting sessions at the site each summer. It is important to point out that the sensor indicated the number of times a person has passed the sensor 
https://doi.org/10.5194/nhess-2021-128

Preprint. Discussion started: 27 April 2021

(c) Author(s) 2021. CC BY 4.0 License.

245 and not the number of individuals climbing the Mont Blanc: a climber who climbed up Mont Blanc and got back down was counted twice by the sensor.

\section{Results}

\subsection{Rockfalls in the Grand Couloir du Goûter during the summer 2019}

In 2019, over 68 days of acquisitions (29/06 to 03/09), 26,339 signals were detected. 2,648 were classified as corresponding

to rockfalls located inside the couloir. It gives an average of 39 events per day. A rockfall is thus recorded every 37 minutes on average indicating a significant geomorphic activity. The number of events is lower in the second half of the season: $72 \%$ of the events are recorded in July against $28 \%$ in August.

The energy of an event measured in 2019 is 0.16 megajoules in average. 88\% of the events recorded have an energy lower than the average (Fig. 4). Conversely, the number of events with a very high energy (> 4 megajoules, i.e. an energy at least 25 times greater than the average; Fig. 4) is relatively low compared to the total number of rockfalls: 19 events, i.e. $0.7 \%$ of the total. In 2019, with the exception of the 29/06, all the most energetic events occurred after July $27^{\text {th }}$ (Fig. 4). The snow potentially dampened the impacts of the blocks in early July. However, as the majority of the couloir was not covered by snow, it can be estimated that a large-scale event would have been measured as such anyway.
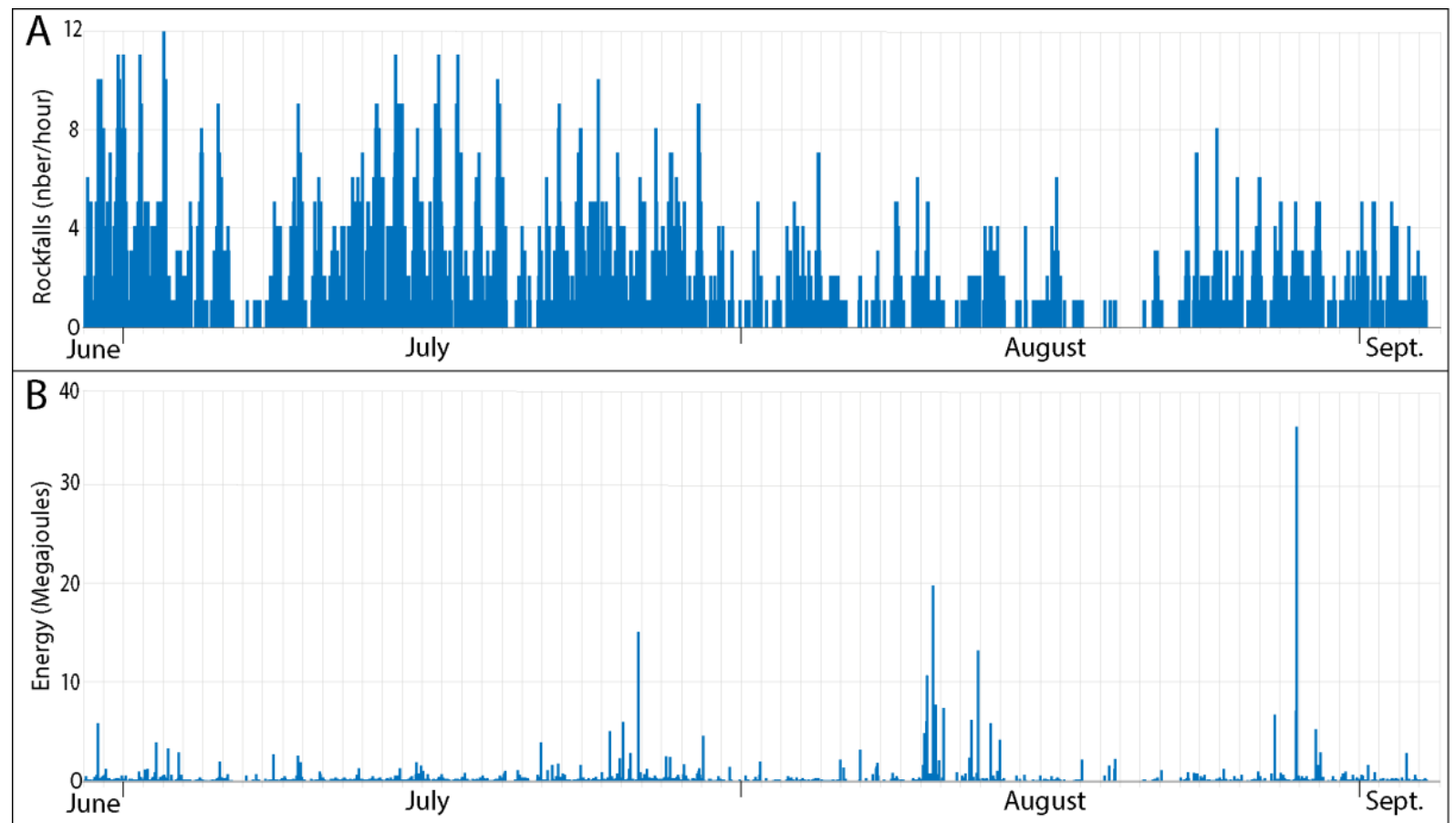

Figure 4: Seismic records in 2019. A. Number of rockfalls per hour. B. Maximum energy of each rock destabilization. 
On average, on a daily basis, rockfalls are distributed as follows (Fig. 5): the period with the lowest activity is in the morning between 2 am and 12 pm, with a minimum of hourly activity between 9 am and 10 am (1 event every 85 min.). The activity then increases markedly between midday and $8 \mathrm{pm}$ with a maximum frequency between $6 \mathrm{pm}$ and $7 \mathrm{pm}$ (1 event every 17 min.). Then, the frequency decreases progressively, until $9 \mathrm{am}$. The most energetic rockfalls occur between $3 \mathrm{pm}$ and $10 \mathrm{pm}$, when they are also the most frequent (Fig. 5).

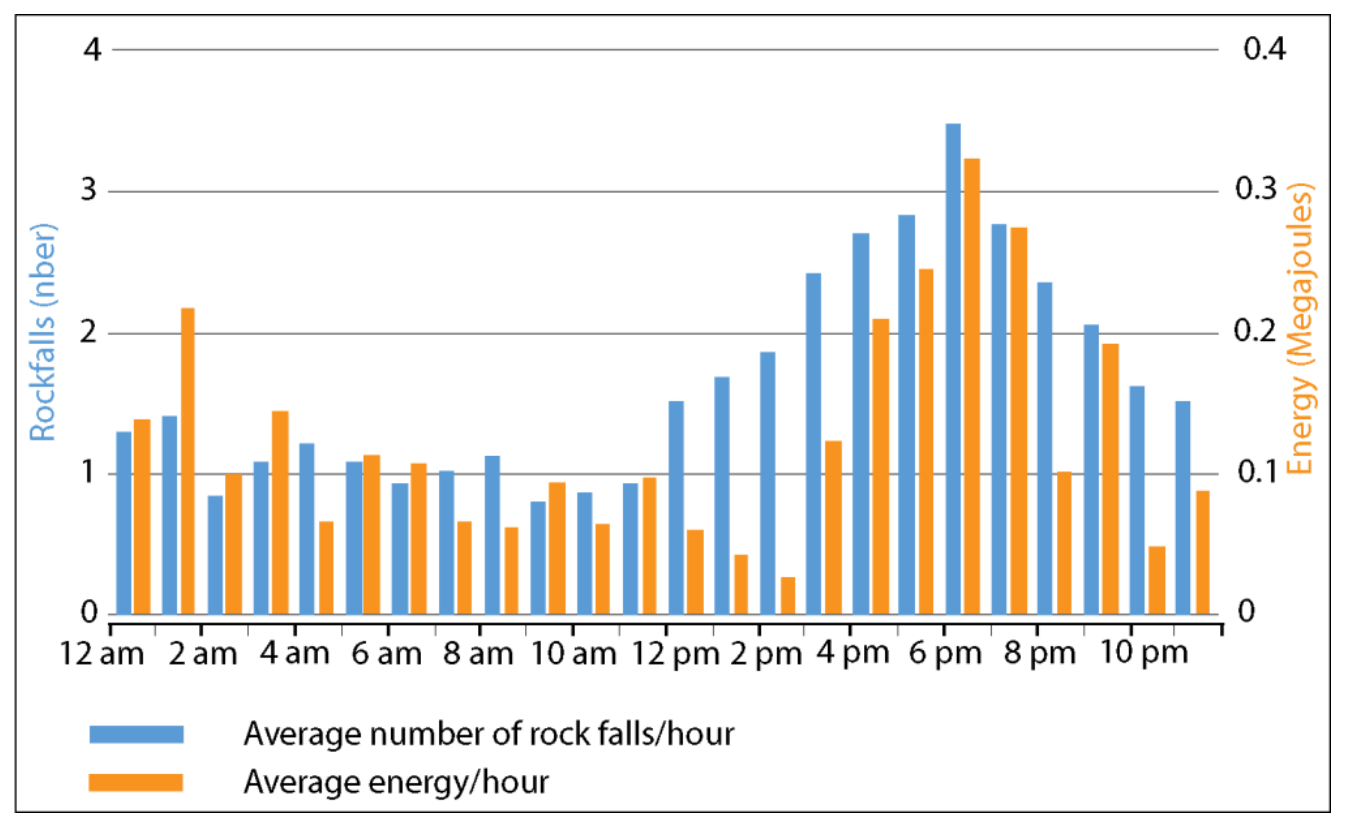

Figure 5: Evolution over 24 hours of (i) the average number of rockfalls per hour and (ii) the average energy of a rockfall per hour.

\subsection{Air temperature}

According to semi-hourly measurements from the Tête Rousse meteorological station, at 3,126 m a.s.l., the average temperature over the period $29 / 06$ to $04 / 09$ was $5.8^{\circ} \mathrm{C}$ with a maximum at $15^{\circ} \mathrm{C}(24 / 07)$ and a minimum at $-2.9^{\circ} \mathrm{C}(15 / 07)$. Over the whole period, there were only 3 FTC associated to three short periods with negative air temperatures, one of 15 hours (15/07), another of 17 hours (13/08) and the last of 4 hours (13/08). At the top of the couloir, at the level of the Goûter refuge $\left(3,817 \mathrm{~m}\right.$ a.s.l.), over the same period, the average temperature was $0.2^{\circ} \mathrm{C}$ with a maximum of $9.9^{\circ} \mathrm{C}(25 / 07)$, a minimum of $15.9^{\circ} \mathrm{C}(02 / 08)$ and there were $39 \mathrm{FTCs}$, with an average of 0.5 cycles per day.

\subsection{Rock temperature evolution and permafrost distribution}

In situ measurements of subsurface temperatures over two years (2018 and 2019) confirm the presence of permafrost in the Grand Couloir du Goûter. The lower part of the couloir is located near the lower permafrost limit with an annual mean temperature of $-1.1^{\circ} \mathrm{C}$ (sensor $\mathrm{C} 1,3,345 \mathrm{~m}$ a.s.1.). The temperature is lower in the middle and upper parts of the couloir, with 
https://doi.org/10.5194/nhess-2021-128

Preprint. Discussion started: 27 April 2021

(c) Author(s) 2021. CC BY 4.0 License.

(c) (1)

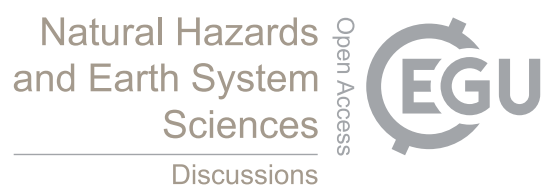

an annual mean temperature of $-2.8^{\circ} \mathrm{C}$ for $\mathrm{C} 2\left(3,460 \mathrm{~m}\right.$ a.s.1.) and $-3.4^{\circ} \mathrm{C}$ for $\mathrm{C} 3(3,665 \mathrm{~m}$ a.s.1.). These results confirm the

280 permafrost distribution map of the Mont Blanc massif established by Magnin et al. (2015) (Fig. 6.A).

Over the period of rockfall recordings were recorded, the number of EFTC at $10 \mathrm{~cm}$ depth in the rock is very limited. Two EFTC were measured by sensor C3 (upper part of the couloir) and none for sensors $\mathrm{C} 1$ and $\mathrm{C} 2$ in the lower and middle part of the couloir, respectively.

The temperatures at depth, simulated with CRYOGRID2 for the period 2010-2020, show a trend of deepening of the active 285 layer since 2010 from $0.75 \mathrm{~m}$ (2010) to $1.5 \mathrm{~m}$ (2019) (Fig. 6), in response to the general air temperature increase. 


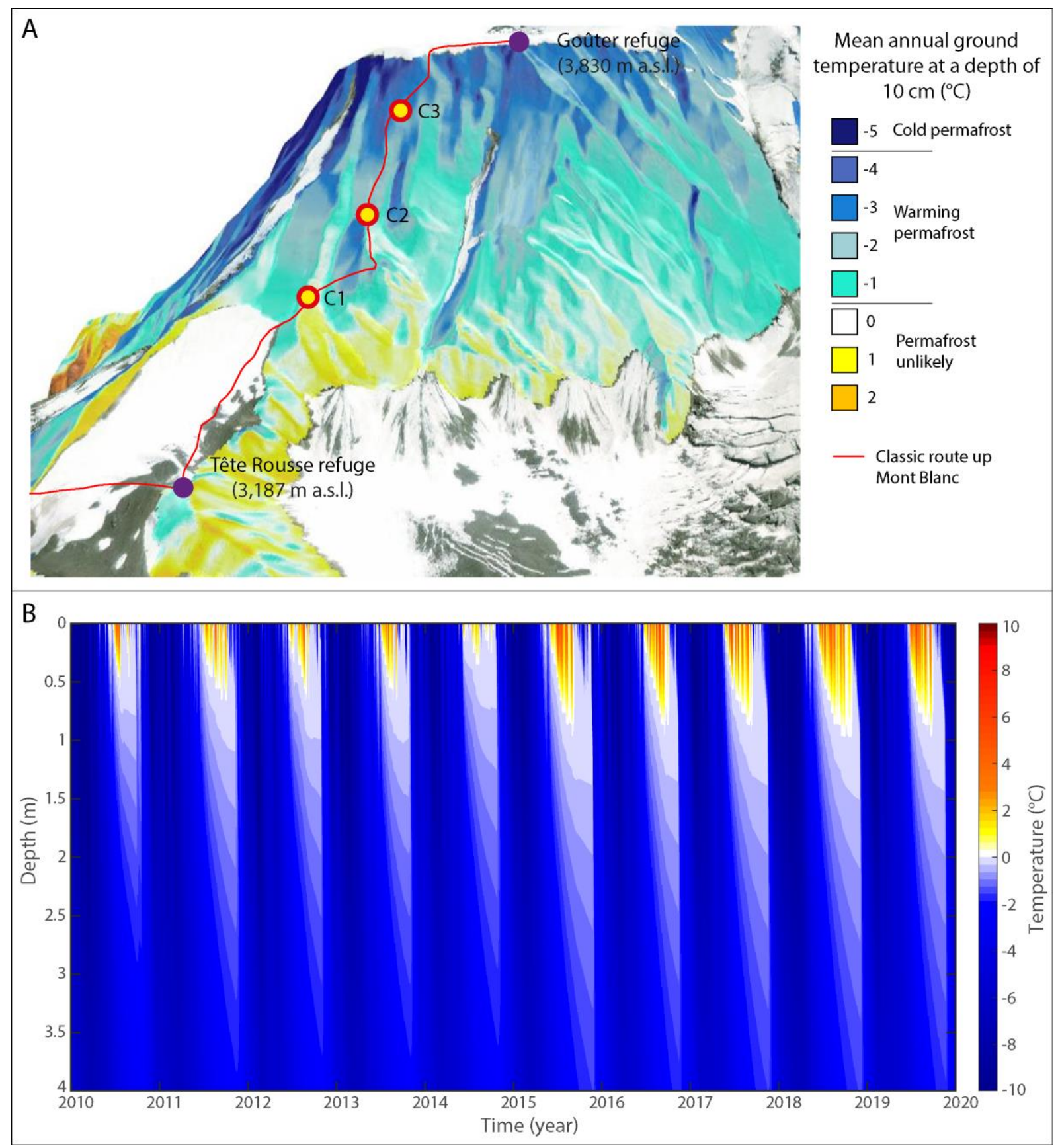

Figure 6: Thermal stat of permafrost and its evolution. A. Permafrost map from the modelling of Magnin et al. 2015 and position of ground temperature sensors. B. Simulation of rock temperatures at the level of sensor C3 with CRYOGRID2 for the period 2010 2020. 


\section{$290 \quad 5.4$ Evolution of snow-covered areas}

During the summer 2019, measurements of snow surfaces in the couloir cover the period 29/06 to 04/09. The snow-covered surfaces show a progressive decrease between $29 / 06$ and 31/07. At this date, only a small residual snow pack was still present in the center of the couloir (Fig. 8). From 01/08 to 04/09, the corridor was completely free of snow except for the period from $20 / 08$ to $25 / 08$ when the whole couloir was powdered with $\sim 5 \mathrm{~cm}$ of snow which completely melted in five days. On $08 / 08$ and $28 / 08$, the upper part of the couloir was powdered with snow that melted in a few hours.

\subsection{Climber traffic}

The results of the climbers traffic measurements are presented for the summer season 2019 between the 29/06 and the 15/09. Over this period, there were $20,424( \pm 7.2 \%)$ passages on the route, of which $41.9 \%$ were on the way up and $58.1 \%$ on the way down. Some of the climbers come from other routes, in particular from the Trois Mont-Blanc route (via the Aiguille du Midi cable-car and the Cosmiques refuge), from the Italian side of Mont Blanc, or from the Aiguille de Bionnassay and use the Goûter route on the way down. The daily number of climbers is slightly higher in July (271) than in August (248). Over the whole season, the number of climbers is very dependent on the weather. When the weather deteriorates, the number of visitors decreases. Conversely, a window of one or two days of good weather is enough to increase, sometime significantly, the number of climbers again (Fig. 7.A).

305 On average, there are 259 passages per day, which are organised according to the time profile displayed on Figure 7.B. The maximum was 497 passages in one day (14/08). On the way up, there are two initial peaks in traffic at 2-3 am and 5-6 am. These correspond to the two starts from the Tête Rousse refuge. Then, there is a main peak between 10 am and 3 pm, corresponding to all the climbers coming from the Mont Blanc tramway. The first train reach the Nid d'Aigle at the earliest at $8.30 \mathrm{am}$. Therefore, the first climbers reach the couloir at around $10 \mathrm{am}$. On the way down, there is a peak between 7 am and

3103 pm, with a maximum between 9 am and 10 am which corresponds to all the climbers coming down. As a result, the vast majority of climbers cross the couloir between $10 \mathrm{am}$ and $2 \mathrm{pm}$, with a peak between $12 \mathrm{pm}$ and $1 \mathrm{pm}$. In one hour, $12.7 \%$ of the daily total of climbers cross the couloir. 


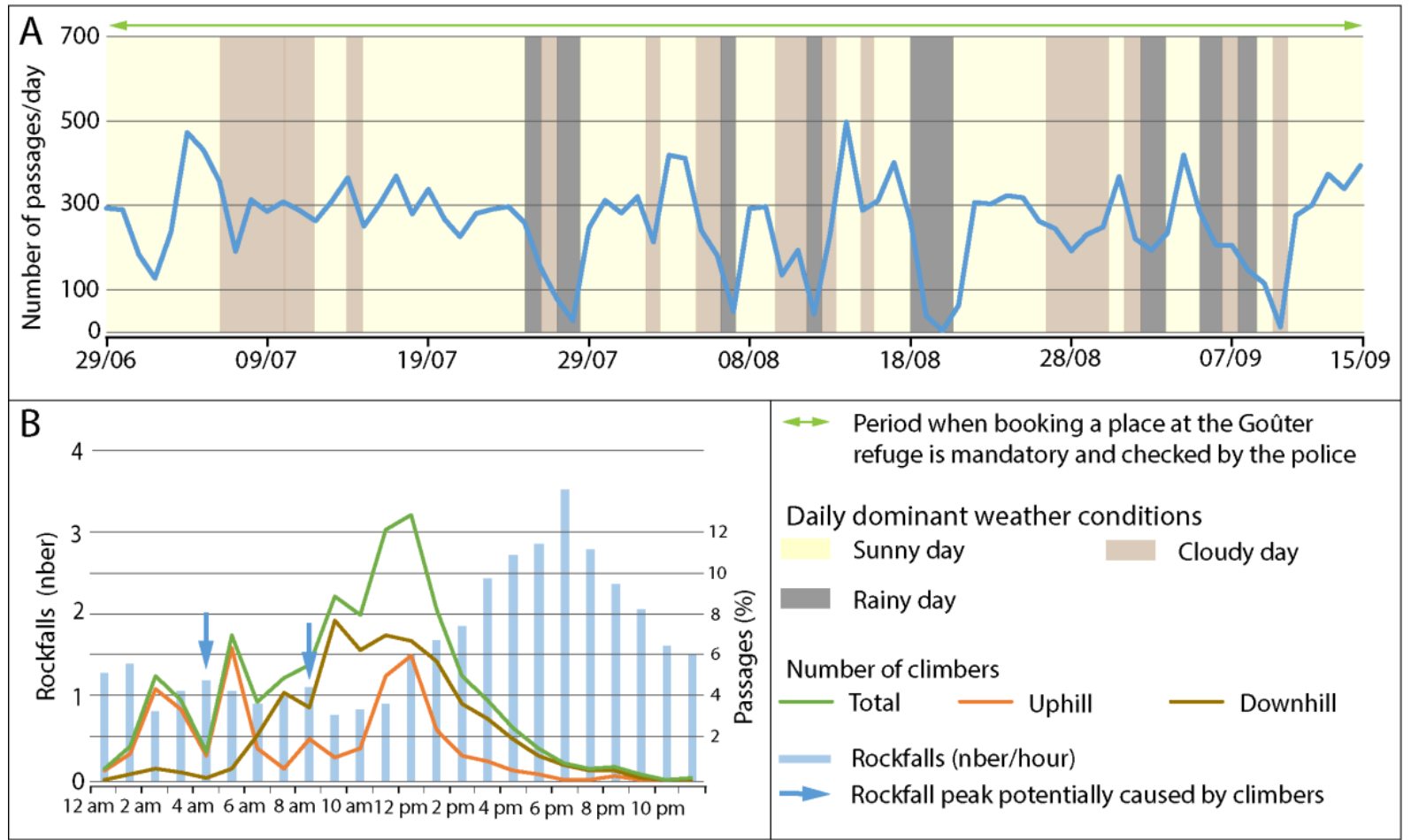

Figure 7: A. Daily variation of climber traffic during the summers 2019. B. Average hourly distribution of climber traffic during the summers 2019 and evolution of the average number of rockfalls per hour.

\section{Discussion}

We can distinguish 3 periods in 2019 according to the daily occurrence of rockfalls (Fig. 8). Period 1 covers the first half of the season (29/06 to 30/07, i.e. 32 days), characterized by the highest rockfall frequency (1916 events, i.e. 1 every 24 min.). Then, Period 2 (31/07 to 22/08, i.e. 23 days) displays a clear decrease in the rockfall frequency with 353 events, i.e. 1 every 94 minutes. Finally, Period 3 (23/08 to 04/09, i.e. 13 days) shows a slight increase in the frequency (379 events measured, i.e. 1 every 49 min.). In this section, the factors conditioning rockfalls will be discussed according to these 3 periods.

\subsection{Factors controlling rockfalls occurrences}

On a seasonal scale, rockfalls are very numerous during the snow cover melting period (Fig. 8 - Period 1). Then, their frequency sharply and rapidly decreases when snow disappears in the couloir or when only a small residual firn is still present in the lower part of the couloir, at the level of the traverse (Fig. 8 - Periods 2 and 3). This finding is in agreement with previous observations in high alpine environments (Krautblatter et al. 2013; Draebing et al. 2014; Draebing et al. 2017; Weber et al. 2018) indicating that the first favourable period for rock instability after the cold season is the period of snowpack melt. The gradual melting produces liquid water that infiltrates into rock cracks - particularly fractured in the study area - on the margins of snow-covered surfaces (Strass, 2005). This causes the rock to heat up by advection and the ice to melt in the cracks (Hasler 
et al. 2011). This results in the deepening of the active layer (Gruber and Haeberli, 2007) and a decrease in the strength of the ice joints (Krautblatter et al. 2013; Mamot et al. 2018), which leads to a decrease in the rockwall stability (Mellor, 1971, 1973; Draebing et al. 2014). In parallel, the presence of water in the cracks leads to an increase in hydrostatic pressure. The presence of moisture in the cracks is usually favoured by a northern orientation, by exposure to the wind which brings precipitation (Strass, 2005) and by a high elevation (Draebing, 2020). Therefore, the presence of moisture in the cracks of the Grand Couloir $d u$ Goûter is certainly favoured by its western orientation and its elevation. In addition, the rock surfaces recently cleared of snow are heated by conduction, which further contributes to the thickening of the permafrost active layer. Meltwater can also eventually refreeze, especially in connection with night-time refreezing, and lead to an increase in cryostatic pressure (Wegmann and Gudmundsson, 1999; Krautblatter, 2010; Hasler et al. 2012; Blikra and Christiansen, 2014; Luethi et al. 2015). However, the latter phenomenon is limited in this study area as the rock temperature at $10 \mathrm{~cm}$ depth remains positive during almost the entire summer season (Fig. 8). Similar situations where the infiltration of snow melt water leads to the deepening of the active layer through advective heat transfer in fractured permafrost terrain, the melting of ice in the cracks and the opening of the cracks, thus promoting rockfalls, have been observed by many authors (Wegmann and Gudmundsson, 1999; Krautblatter, 2010; Hasler et al. 2012; Blikra and Christiansen, 2014; Luethi et al. 2015).

Conversely, during Periods 2 and 3 when the couloir is completely cleared of snow, the quantity of water present in the rock is lower, limiting the action of the thermo-mechanical processes involved in the rockfall triggering (Fig. 1). The thickening of the permafrost active layer only continues by conduction and, occasionally, by advection during precipitation. As a result, the frequency of rock destabilization is two times lower than during Period 1.

The most energetic rockfalls occur during Periods 2 and 3 (15 out of 19 events). This finding is in agreement with previous studies on rockfalls in the Mont Blanc massif (e.g. Ravanel and Deline, 2010; Ravanel et al. 2017) indicating that permafrost degradation leads to an increase in rockfall mobilizing large volumes (rock collapse type, $\mathrm{V}>100 \mathrm{~m}^{3}$ ), mostly in sectors where the rock is highly fractured, and in particular at the end of the summer season when the penetration of the seasonal heat wave in the rock is already well advanced and the active layer is the deepest (Legay et al. in rev.). According to these studies, the events mainly occur on slopes between 40 and $60^{\circ}$, between 3,400 and 3,500 $\mathrm{m}$ a.s.1., an altitudinal range where the permafrost often reaches mean annual surface temperatures between -2 and $0^{\circ} \mathrm{C}$ at a depth of $10 \mathrm{~cm}$. Also, the Grand Couloir du Goûter, located between 3,200 and 3,800 m a.s.l. (the lower part of the couloir corresponds to the lower limit of the permafrost; Fig. 6.A), with a slope angle of 45 to $60^{\circ}$, constituted by highly fractured gneiss, and with an active layer that reaches its maximum thickness in September (1.5 $\mathrm{m}$ in 2019 according to the CRYOGRID2 modelling, Fig. 6.B) brings together conditions that are particularly prone to the occurrence of such rock collapses due to permafrost degradation. Moreover, the most energetic rockfalls occurred mostly (16 out of 19 events) during precipitations or in the following 24 hours, which suggests once more the key role played by liquid water infiltration in rock cracks in triggering destabilisations, including the largest ones. 


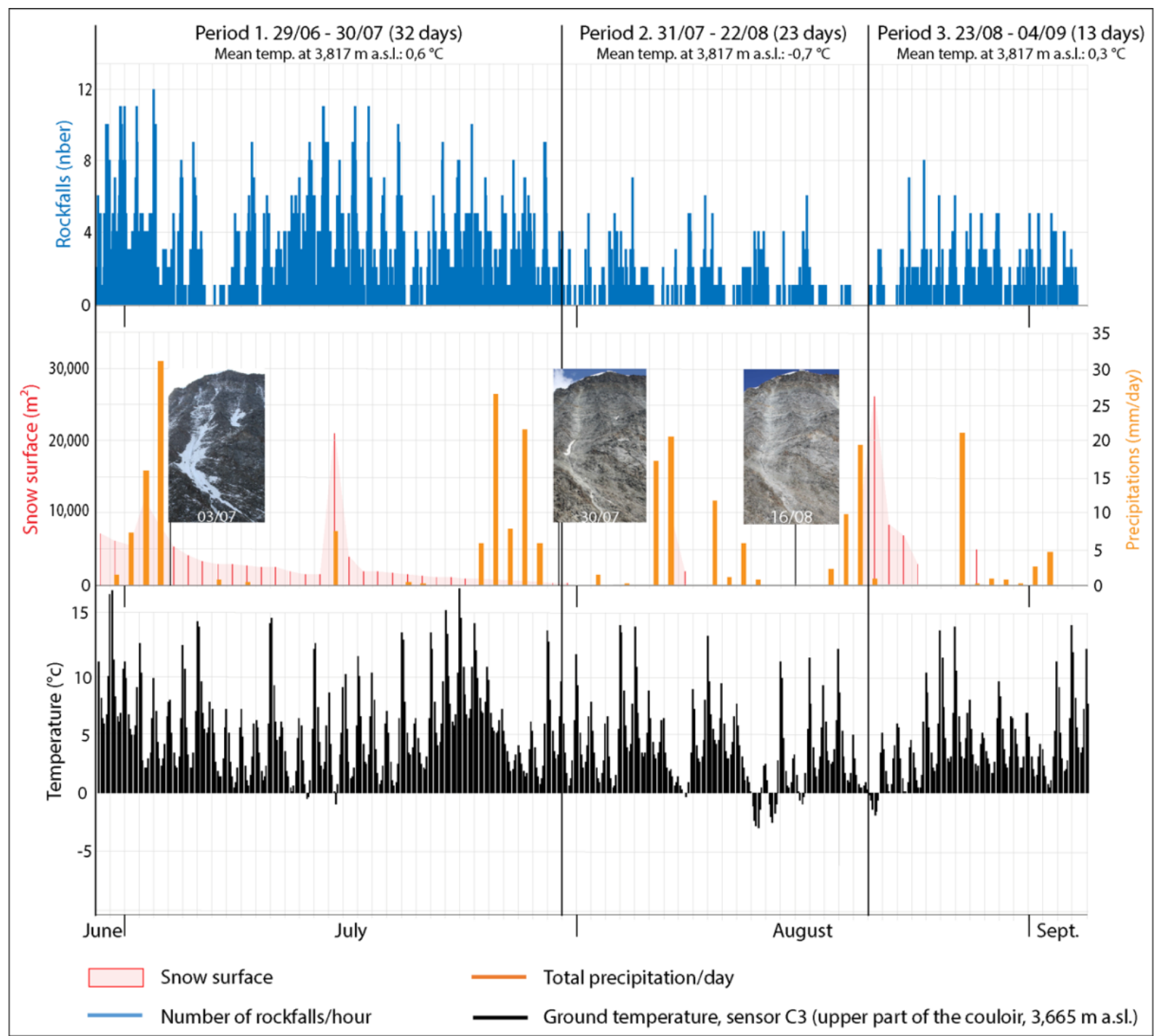

Figure 8: Comparison between the number of rockfalls per hour and the evolution of the snow-covered surfaces, precipitations and ground temperature on the upper part of the couloir (sensor C3).

On a daily scale, the number of rockfalls correlated with the air temperature and consequently with the rock temperature (Fig.

9). The number of events starts to increase on average $3 \mathrm{~h}$ after the return of positive air temperature at the top of the couloir. The rockfall frequency increases between $1 \mathrm{pm}$ and $7 \mathrm{pm}$ with a maximum between $6 \mathrm{pm}$ and $7 \mathrm{pm}$ (Fig. 5). This maximum occurs on average, over the whole season, 6 hours after the warmest air temperature of the day at the top of the couloir and 3 hours after the warmest temperature at Tête Rousse. Conversely, the time of the day with the lowest rockfall frequency is between 9 am and $12 \mathrm{pm}$, after the coldest period of the day (between $11 \mathrm{pm}$ and $7 \mathrm{am}$ ). There is therefore a time lag of several hours between the maximum/minimum air temperatures and the rockfalls, which is probably linked to the thermal inertia of the snow and the rock surface. Moreover, the number of events starts to increase when the couloir gradually turns into the sun, 
between $12 \mathrm{pm}$ and $1 \mathrm{pm}$ at the beginning of the season, and between $1 \mathrm{pm}$ and $2 \mathrm{pm}$ at the end of the season. The number of rockfalls only starts to decrease after $8 \mathrm{pm}$, which corresponds to the moment when the air temperature at the top of the couloir falls below $0^{\circ} \mathrm{C}$. The nightly refreezing and the daytime thawing at the top of the couloir thus seem to have an effect on the rockfall triggering.

Specifically, despite the same number of EFTC in Periods 1 and 2 (based on air temperature at the top of the couloir), rockfalls are twice as frequent in Period 1 (Fig. 8). It highlights the importance of the snow melt, the increased hydrostatic pressures and the melting of ice in the cracks in the rockfall triggering. Period 2 is also the coldest (average air temperature of $-0.7^{\circ} \mathrm{C}$ at the top of the couloir) with a relatively limited and short daily thaw (mean hourly temperatures are between -1.7 and $0.7^{\circ} \mathrm{C} ; 8$ hours per day of positive air temperature compared with 13 hours for the Period 1; Fig. 9) which limits the action of all the thermo-mechanical processes. When the couloir is completely clear of snow (Periods 2 and 3), the number of rockfalls is greater in Period 3 ( 1 event every 94 min in Period 2 compared with 1 every $39 \mathrm{~min}$ in Period 3). It is likely that this difference is related to the more pronounced freeze-thaw cycles during Period 3 (mean hourly temperatures are between 2.6 and $-1.5^{\circ} \mathrm{C}$ ) for a daily thaw period of 11 hours (Fig. 9). Moreover, during this last period, the thermo-mechanical processes are probably all the more effective as the melting of the snow that fell on August $20^{\text {th }}-21^{\text {st }}$ brings liquid water into the cracks of the rock (Fig. 8). However, the fact that there is no refreezing of the rock at $10 \mathrm{~cm}$ depth (Fig. 8) underlines the weak morphogenic potential of daily freeze-thaw cycles and thus their limited role in triggering events. It is likely that nocturnal refreezing (indicated by air temperatures at the Goûter station and associated with radiative cooling of the surface) only has an impact on the first few centimeters below the rock surface with relatively low cryostatic pressures (Matsuoka, 1990; Seto, 2010). It probably leads to the cementation of only the finest elements, a halt in the melting of the snow present during Period 1 and the resulting processes, and thus reduces the frequency of destabilization. On the contrary, the progressive increase in temperature during the morning reactivates the melting of the snow and all the associated thermo-mechanical processes and, in particular, the supply of liquid water into the cracks which implies an increase in the rockfall frequency. The clear link between air/rock temperatures and the rockfall frequency also suggests that some of the destabilizations may be triggered by conductive expansion of the rock during the warmest hours of the day (Collins and Stock, 2016).

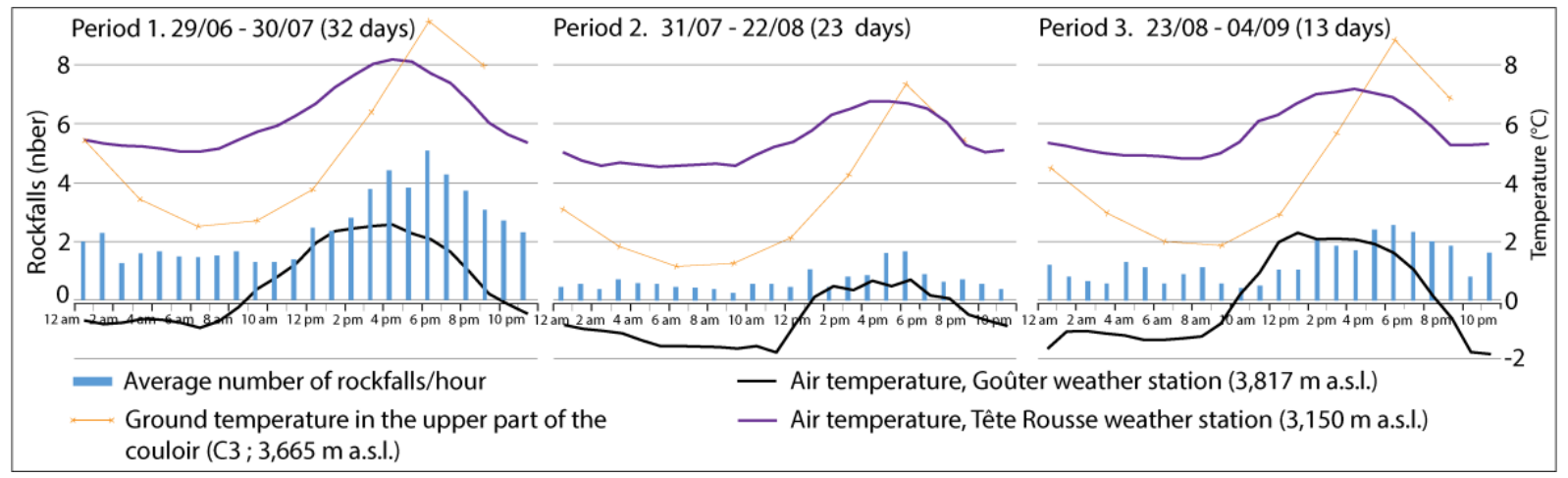


Figure 9: Evolution over $24 \mathrm{~h}$, for the Periods 1, 2 and 3, of (i) the average number of rockfalls per hour, (ii) the mean hourly ground temperature in the upper part of the couloir (C3) and (iii) the mean hourly air temperature at the Tête Rousse and the Goûter weather stations.

Various mechanical processes can thus trigger rockfalls in the Grand Couloir du Goûter. These are influenced by thermal factors conditioned by meteorological parameters (air temperature, precipitation, and snow melt). Under the conditions of our study, it remains difficult to determine precisely which process - or combination of processes - triggers the rockfalls. During the snowmelt period (Period 1), it is difficult to know whether it is the ice melt in the cracks by meltwater infiltration or by convection/conduction of heat, the alternation of daily freeze-thaw cycles on the surface, the hydraulic pressures increase or the flow of water on the surface that causes most of the destabilization. In the topographic conditions of the Grand Couloir du Goûter, the periods of snowmelt, constrained by the seasonal increase in air temperatures, are the periods when the thermomechanical processes favouring the occurrence of rockfalls are the most active (Fig. 1). Conversely, the action of these processes is inhibited when the couloir is cleared of snow, suggesting the important role of water in its liquid state.

\subsection{Climbers' traffic and rockfalls}

410 The number of climbers following the route does not vary according to the frequency of rockfalls and climbers take little to no account of rockfalls when planning their ascent.

Indeed, on a seasonal scale, frequent or - conversely - very rare rockfalls do not lead to a change in the number of climbers. In 2019, for the same number of days of good weather, there were as many passages in July $(8,408)$ as in August $(7,708)$, whereas rockfalls were 2.6 times more frequent in July. The number of climbers is mainly determined by the weather and probably by other socio-economic factors and management of the route, such as the refuges booking procedures.

In terms of accidents, between 1990 and 2017, there were as many rescue operations in July as in August (114 and 113 respectively) and as many in June as in September (54; Mourey et al. 2018). However, the measurements carried out in 2019 show that the rockfall frequency and the factors that condition them are very variable during the same season. This observation reinforces the assumption that the number of accidents is mainly correlated to the number of climbers, which is very similar in July and August, as well as in June and September.

On a daily scale, over the period 1990-2017, the intervention of the professional rescuers for an accident is demanded on average around $1 \mathrm{pm}$ (Mourey et al. 2018). This corresponds to the time when there are the most people in the area of the Grand Couloir sector, with a number of rockfalls that has already doubled compared to mid-morning. Furthermore, when the rockfalls are the most frequent, i.e. between $6 \mathrm{pm}$ and $8 \mathrm{pm}$, the number of climbers is reduced. This observation confirms the need for climbers arriving from the Nid d'Aigle to cross the couloir as early as possible, if possible before midday when the west face of the Aiguille du Goûter is still in the shade, and not to wait until the end of the afternoon or the beginning of the evening which is the most dangerous period of the day, as some climbers do, in order to avoid arriving too early at the Goûter refuge. 
According to our observations on the field, some rockfalls are triggered by the climbers themselves, from the upper left part

of the couloir. The data acquired do not allow us to measure precisely the anthropogenic part of the rockfalls. However, there are two time periods when the number of rockfalls increases slightly: during the night, between 4 am and 5 am, and in the morning, between 8 am and 9 am, i.e. 2 or 3 hours after the first traffic peaks at the bottom of the couloir (at 2-3 am and 5-6 am, respectively; Fig. 7.B). This 2-3 hours time-delay between the peaks of traffic and rockfall frequency corresponds to the time needed for climbers to reach the upper part of the couloir from the traverse, where they are the most likely to trigger rockfalls. Thus, these slight increases in the number of events could be - at least partly - associated with an anthropogenic triggering.

\subsection{Limitations of the study and perspectives}

Firstly, the smallest rockfalls or those without marked impacts in the couloir - yet potentially fatal for climbers - are not necessarily detected in our study, which rejects all the signals of uncertain sources ( $\sim 50 \%$ of the total number of signals). The detection of the small rockfalls in the seismic records could therefore be improved using deep learning algorithms (e.g. Hibert et al. 2017), trained on sample signals checked on the field.

Secondly, it would be interesting to maintain seismic instrumentation for longer periods at the beginning and end of the summer season. According to the temperature measurements in the rock in the upper part of the couloir, the periods in which freezethaw cycles are most numerous occur in May-June and October-November. Also, the seismic sensors measuring the rockfall occurrences were installed too late and de-installed too early to study the effect of a high frequency of daily freeze-thaw cycles on rockfalls. However, it can be estimated that in spring, as the snow insulates the ground from air temperature variations, frost weathering is rather limited, except perhaps at the level of the rock ridges (potentially important suppliers of rocky material) on the sides of the couloir, which are generally not covered by a thick snow cover. During summer, the couloir is clear of snow but a refreezing at $10 \mathrm{~cm}$ depth in the rock almost never happens. There can therefore be no - or only limited increase in cryostatic pressures. The action of processes linked to the heating of the rock by convection and conduction, and to the infiltration of liquid water into the fractures in the rock, are therefore favoured. Conversely, in the Autumn, the freezethaw cycles are favoured by the absence of snow in the couloir. Furthermore, although a first field test was carried out during the summer of 2018 with 3 seismometers (Le3D Lennartz) installed on the right bank of the couloir and operational for 3 weeks with results comparable to 2019 (number of events, daily and seasonal distribution), the analysis presented here only covered one season. It would be interesting to compare to other seasons to assess the reproducibility of the results.

In order to better quantify the triggering processes, further measurements, including pressure and crack opening/closing sensors (strain gauges, inclinometers; McColl and Draebing, 2019; Weber et al. 2019) would have been required.

Finally, the evolution of the snow cover in the couloir, identified in this study as an important factor in the rockfall triggering, was only evaluated from snow-covered surface data which only gives biased information on the quantity of liquid water

460 available during melting. For a powdering of snow or a fall of several decimetres of snow on the whole couloir, the snowcovered surfaces will be very similar whereas the quantity of liquid water resulting from the melting are very different. 


\section{Climate change and future projections}

In the current socio-economic and cultural context, the Mont Blanc is likely to remain one of the most climbed peaks in the world. However, climate change is likely to lead to an increase in rockfalls, mainly due to the permafrost degradation. Indeed, in the Alps, it is estimated that the climate will warm by $3-4^{\circ} \mathrm{C}$ in winter and $3-7^{\circ} \mathrm{C}$ in summer by 2100 (IPCC, 2019; RCP 8.5 scenario). This rise in temperature will inevitably have a potentially significant effect on rockfalls regime in the Grand Couloir $d u$ Goûter. The $0^{\circ} \mathrm{C}$ isotherm is expected to rise by $400 \mathrm{~m}$ in summer (RCP 8.5 scenario), from 3,800 $\mathrm{m}$ today to 4,200 $\mathrm{m}$ a.s.l. in 2050, leaving only a few areas of the MBM outside the melt zone (Cremonese et al. 2019). In parallel, the freezing frequency will decrease by $45-50$ percentage points between 3,500 and 4,500 $\mathrm{m}$ a.s.l. by 2100 based on the RCP 8.5 scenario (Pohl et al. 2019). This will reduce the daily-scale frost weathering. Snowmelt will occur ever earlier in the summer season and probably over a shorter period. As a result, a significant amount of liquid water will infiltrate into the cracks of the rock but over a shorter period of time. Although precipitation does not show a decreasing trend in the Alps, the frequency of intense episodes of precipitation will increase (Météo France data - Drias-climat). This implies that large quantities of liquid water could punctually infiltrate the cracks of the rock. It is therefore likely that rockfalls linked to liquid water infiltration and the resulting thermo-mechanical processes will be particularly frequent but possibly over shorter periods. Finally, the ongoing degradation of permafrost will continue and intensify (Magnin et al., 2017; Biskaborn et al. 2019). It can therefore be estimated that the most voluminous rockfalls that tend to occur at the end of the summer season or in favor of heatwaves - which are also more frequent (Della-Marta et al. 2007) - will be enhanced with an active layer that will become increasingly deep.

\section{Conclusions}

Our results show that in the high-Alpine and permafrost-affected Aiguille du Goûter west face, rockfalls are mostly frequent at the beginning of the summer season, i.e. during the snowmelt period which favors the action of thermo-mechanical processes linked to the infiltration of liquid water into the cracks of the rock. During periods when the couloir is completely clear of snow, rockfalls are 2.5 times less frequent, and the thermo-mechanical processes involved in the rockfall triggering are limited by the absence of moisture in the ground. The most energetic events are occurring at the end of the summer season, as deep warming of the terrain reaches its maximum. These field results confirm the conceptual approach proposed by Draebing and Krautblatter (2014) who identified early summer season has a period particularly prone to rockfalls in context of permafrost due to snow melt and liquid water infiltration into the rock cracks, and autumn with the penetration of the summer heat wave deep into the rock.

These results also allow a better evaluation of climbers' vulnerability in this sector and show that climbers' awareness of the risk of rockfalls remains limited. What's more, they do not adapt - or only slightly - their behavior to this risk, despite a particularly high accident rate. Important work on prevention and dissemination of the knowledge here acquired (newsletters, training for professionals and amateurs, awareness campaigns) among mountaineers is therefore still really necessary. 
The study we carried out applied the recommendations of McDowel and Koppes (2017) (i) to acquire interdisciplinary, precise data at a fine scale in order to take into account the specificities of the study area and not to simply transpose dynamics visible at larger scales; (ii) to take into account the complex interactions existing between changes in the physical environment and the socio-economic, cultural and political conditions specific to a study area, the implementation of adaptation strategies being not solely guided by physical changes in the environment; and (iii) to recommend adaptation methods adapted to the context in order to lead to appropriate adaptation plans. At the Grand Couloir du Goûter, we acquired interdisciplinary data on a fine scale in partnership with the main actors concerned (local authorities, the French Federation of Alpine Clubs, the military forces in charge of the rescue operations, and hut keepers). This has certainly contributed to the good reception of the first results which have been disseminated to the mountain community and to the actors in charge of the management of the route through a research report (available for free in French and English on the Petzl Foundation website) and a web video clip (viewed more than 500,000 times and projected at the Science and Mountains Festival in Grenoble), and has enabled the concertation process to be re-launched in order to adapt the management of the route and the prevention measures applied to mountaineers.

\section{Author contribution}

JM, PL and PAD conceived the study, realized most of the field missions and analyzed the data from different sensors (PL: seismic sensors; PAD: ground temperature sensors and temperatures modelling; JM: weather stations and traffic sensor). JM analyzed the full set of data and wrote the article with the analysis contributions of PL, PAD and LR. GM and MM participated to some of the field missions and made the analysis of the snow-covered surfaces. LR acquired the DTM on the field and contributed to the funding of the study. EM participated to most of the field mission, designed the automatic camera system and his technical skills were indispensable for the installation and maintenance of all the measurement systems and data storage.

\section{Competing interests}

515 The authors declare that they have no conflict of interest.

\section{Acknowledgements}

The authors warmly thank Olivier Moret and the Petzl Foundation for their support, Didier Hantz (ISTerre) and Florence Magnin (EDYTEM) for their help in analysing the data, Pierre Dubois (REQUEA) for giving us access to data from their weather station, Antoine Rabatel (IGE) for lending the long rang Lidar and Emmanuel Thibert (INRAE) for the access to the 
(ISTerre) for their help on the field and in setting up the seismometers, and Bertrand Guillet for lending us the seismic measurement equipment. We would also like to thank the town of Saint-Gervais for its support in carrying out this work, the Compagnie du Mont-Blanc for granting us free access to the site and all the people who helped us in the field to carry and set up the equipment. This study was financed by the EU ALCOTRA AdaPT Mont-Blanc project and the Petzl Foundation.

\section{References}

Allen, S., and Huggel, C.: Extremely warm temperatures as a potential cause of recent high mountain rockfall, Global and Planetary Change, 107: 59-69, https://doi.org/10.1016/j.gloplacha.2013.04.007, 2011.

Alpes Ingé.: Couloir du Goûter, Suivi et analyse des chutes de blocs et de la fréquentation pendant l'été 2011, Rapport final, Fondation Petzl, 37, 2012.

530 Beniston, M., Farinotti, D., Stoffel, M., Andreassen, L.M., Coppola, E., Eckert, N., Fantini, A., Giacona, F., Hauck, C., Huss, M., Huwald, H., Lehning, M., López-Moreno, J.-I., Magnusson, J., Marty, C., Morán-Tejéda, E., Morin, S., Naaim, M., Provenzale, A., Rabatel, A., Six, D., Stötter, J., Strasser, U., Terzago, S., Vincent, C.: The European mountain cryosphere: a review of its current state, trends, and future challenges, The Cryosphere 12, 759-794, https://doi.org/10.5194/tc-12-759-2018, 2018.

535 Biskaborn, B., Smith, S., Noetzli, J., Matthes, H., Vieira, G., Streletskiy, D., Schoeneich, P., Romanovsky, V., Lewkowicz, A., Abramov, A., Allard, M., Boike, J., Cable, W., Christiansen, A., Delaloye, R., Diekmann, B., Drozdov, D., Etzelmüller, B., Grosse, G., Guglielmin, M., Ingeman-Nielsen, T., Isaksen, K., Ishikawa, M., Johansson, M., Johannsson, H., Joo, A., Kaverin, D., Kholodov, A., Konstantinov, P., Kröger, T., Lambiel, C., Lanckman, J-P., Luo, D., Malkova, G., Meiklejohn, I., Moskalenko, N., Oliva, M., Phillips, M., Ramos, M., Sannel, A., Sergeev, D., Seybold, C., Skryabin, P., Vasiliev, A., Wu, Q.,

540 Yoshikawa, K., Zheleznyak, M., Lantuit, H.: Permafrost is warming at a globale scale. Nature Communications, 10-1, https://doi.org/10.1038/s41467-018-08240-4, 2019.

Blikra, LH. and Christiansen, HH.: A field-based model of permafrost-controlled rockslide deformation in northern Norway, Geomorphology, 208:34-49, https://doi.org/10.1016/j.geomorph.2013.11.014, 2014.

Collins, B. and Stock, G.: Rockfall triggering by cyclic thermal stressing of exfoliation fractures, Nature Geoscience,

545 https://doi.org/10.1038/ngeo2686, 2016

Cremonese, E., Carlson, B., Filippa, G., Pogliotti, P., Alvarez, I., Fosson, JP., Ravanel, L. and Delestrade, A.: AdaPT MontBlanc : Rapport Climat: Changements climatiques dans le massif du Mont-Blanc et impacts sur les activités humaines. Rédigé dans le cadre du projet AdaPT Mont-Blanc financé par le Programme européen de coopération territoriale Alcotra Italie-France 2014-2020, 101, 2019.

550 Debarbieux, B.: L’Unesco au mont Blanc, Chamonix, Guérin, France, 2020.

Della-Marta, PM., Haylock, MR., Luterbacher, J., Wanner, H.: Doubled length of western European summer heat waves since 1880, Journal of Geophysical Research, 112, https://doi.org/10.1029/2007JD008510, 2007. 
Dietze, M., Mohadjer, S., Turowski, J., Ehlers, T., Hovius, N.: Seismic monitoring of small alpine rockfalls - validity, precision and limitations, Earth Surface Dynamics, 5, 653-668, https://doi.org/10.5194/esurf-5-653-2017, 2017.

Dobinski, W.: Permafrost, Earth-Science Reviews, 108, 158-169, https://doi.org/10.1016/j.earscirev.2011.06.007, 2011.

Draebing, D., Krautblatter, M., Dikau, R.: Interaction of thermal and mechanical processes in steep permafrost rock walls: a conceptual approach, Geomorphology, 226:226-235, https://doi.org/10.1016/j.geomorph.2014.08.009, 2014

Draebing, D., Krautblatter, M., and Hoffmann, T.: Thermo-cryogenic controls of fracture kinematics in permafrost rockwalls, Geophysical Research Letters, 44, https://doi.org/10.1002/2016GL072050, 2017.

Draebing, D.: Identification of rock and fracture kinematics in high Alpine rockwalls under the influence of altitude, Earth Surf. Dynam. Discuss. [preprint], https://doi.org/10.5194/esurf-2020-69, in review, 2020.

Durand, V., Mangeney, A., Haas, F., Jia, X., Bonilla, F., Peltier, A., Hibert, C., Ferrazzini, V., Kowalski, P., Lauret, F., Brunet, C., Satriano, C., Wegner, K., Delorme, A., Villeneuve, N.: On the link between external forcings and slope instabilities in the Piton de la Fournaise summit crater, Reunion island, Journal of Geophysical Research: Earth Surface, 123, 2422-2442. https://doi.org/10.1029/2017JF004507, 2018.

Flöry, S., Ressl, C., Hollaus, M., Pürcher, G., Piermattei, L., and Pfeifer, N.: “Websnow”: estimation of snow cover from freely accessible webcam images in the alps, ISPRS Annals of the Photogrammetry, Remote Sensing and Spatial Information Sciences, 2, 695-701, https://doi.org/10.5194/isprs-annals-V-2-2020-695-2020, 2020.

Fedorov, V., Arias, P., Facciolo, G., Ballester, C.: Affine Invariant Self-similarity for exemplar-based Inpainting. $11^{\text {th }}$ joint Conference on Computer Vision, Imaging and Computer Graphics theory and Applications, 3, 50-60. https://doi.org/10.5220/0005728100480058, 2016.

Gardent, M., Rabatel, A., Dedieu, J.P., Deline, P.: Multitemporal glacier inventory of the French Alps from the late 1960s to the late 2000s, Global and Planetary Change, 120:24-37, https://doi.org/10.1016/j.gloplacha.2014.05.004, 2014

Gruber, S. and Haeberli, W.: Permafrost in steep bedrock slopes and its temperature-related destabilization following climate change. J Geophys Res. https://doi.org/10.1029/2006JF000547, 2007.

Gruber, S., Hoelzle, M., Haeberli, W.: Permafrost thaw and destabilization of Alpine rock walls in the hot summer 2003, Geophysical research letters, 31-13, https://doi.org/10.1029/2004GL020051, 2004.

Harris, C. and Vonder Muhll, D.: Permafrost and Climate in Europe. Climate Change, Mountain Permafrost Degradation and Geotechnical Hazard. In: Visconti, G., Beniston, M., Iannorelli, E.D., Barba, D. (eds) Global Change and Protected Areas.

580 Advances in Global Change Research, vol 9. Springer, Dordrecht. https://doi.org/10.1007/0-306-48051-4_9, 2001.

Hartley, R. and Zisserman, A.: Multiple view geometry in computer vision, Cambridge university press, 48, 2003.

Hasler, A., Gruber, S., Font, M., Dubois, A.: Advective heat transport in Frozen Rock Clefts: conceptual model, laboratory experiments and numerical simulation, Permafrost Periglac Process 22:378-389, https://doi.org/10.1002/ppp.737, 2011.

Hasler, A., Gruber, S., Beutel, J.: Kinematics of steep bedrock permafrost. J Geophys Res Earth Surf, 117, 585 https://doi.org/10.1029/2011jf001981, 2012. 
Helmstetter, A. and Garambois, S.: Seismic monitoring of Séchilienne rockslide (French Alps): Analysis of seismic signals and their correlation with rainfalls, Journal of Geophysical Research, 15, F03016, https://doi:org/10.1029/2009JF001532, 2010.

Hibert, C., Malet, J.-P., Bourrier, F., Provost, F., Berger, F., Bornemann, P., et al.: Single-block rockfall dynamics inferred from seismic signal analysis, Earth Surface Dynamics, 5, 283-292. https://doi.org/10.5194/esurf-5-283-2017, 2017.

Hipp, T., Etzelmüller, B., Westermann, S.: Permafrost in Alpine Rock faces from Jotunheimen and Hurrungane, Southern Norway, Permafrost and Periglacial Processes, 25:1-13, https://doi.org/10.1002/ppp.1799, 2014.

Hoibian, O., and Defrance, J.: Deux siècles d'alpinisme européens. Origines et mutations des activités de grimpe, L'Harmattan, Paris, 2002.

595 IPCC.: Summary for Policymakers. IPCC Special Report on the Ocean and cryosphere in a Changing climate, Working Group I and II, 2019.

Krautblatter, M.: Patterns of multiannual aggradation of permafrost in rock walls with and without hydraulic interconnectivity (Steintälli, Valley of Zermatt, Swiss Alps). In: J. Otto, R. Dikau (Eds.), Landform - Structure, Evolution, Process Control. Proceedings of the International Symposium on Landform organised by the Research Training Group 437, Lecture Notes in 600 Earth Sciences 115, Springer Verlag, Heidelberg, 199-219, 2010.

Krautblatter, M. and Dikau, R.: Towards a uniform concept for the comparison and extrapolation of rockwall retreat and rockfall supply, Geogr. Ann., 89 A (1): 21-40, http://dx.doi.org/10.1111/j.1468-0459.2007.00305.x, 2007.

Krautblatter, M. and Moser, M.: A nonlinear model coupling rockfall and rainfall intensity based on a four year measurement in a high Alpine rock wall (Reintal, German Alps), Nat Hazards Earth Syst Sci, 9:1425, https://doi.org/10.5194/nhess-9-1425$\underline{2009}, 2009$.

Krautblatter, M., Funk, D., Günzel, FK.: Why permafrost rocks become unstable: a rock-ice-mechanical model in time and space, Earth Surf Process Land, 38:876-887, https://doi.org/10.1002/esp.3374, 2013.

Lacroix, P. and Helmstetter, A.: Location of Seismic Signals Associated with Microearthquakes and Rockfalls on the Séchilienne Landslide, French Alps, Bulletin of the Seismological Society of America, 101(1): 341-353, 610 https://doi.org/10.1785/0120100110, 2010.

Lemarchal, D. (EURL Meije): Massif du Mont-Blanc. Traversée du Grand Couloir. Etude de faisabilité et avant-projet de sécurisation. Fondation Petzl, 87, 2011.

Le Roy, G., Helmstetter, A., Amitrano, D., Guyoton, F., Le Roux-Mallouf, R.: Seismic analysis of the detachment and impact phases of rockfalland application for estimating rockfall volume and free-fall height, Journal of geophysical research: Earth 615 surface, 124(11), https://doi.org/10.1029/2019JF004999, 2019.

Legay, A., Magnin, F., Ravanel L., submitted. Rock temperature prior to failure: analysis of 209 rockfall events in the Mont Blanc massif (Western European Alps), submitted to Permafrost and Periglacial Processes. 
Luethi, R., Gruber, S., Ravanel, L.: Modelling transient ground surface temperatures of past rockfall events: towards a better understanding of failure mechanisms in changing periglacial environments, Geografiska Annaler: Series A, Phys. Geogr. 97:753-767, https://doi.org/10.1111/geoa.12114, 2015.

Magnin, F., Brenning, A., Bodin, X., Deline, P., Ravanel, L.: Statistical modelling of rock wall permafrost distribution: application to the Mont Blanc massif, Geomorphologie, 21:145-162, https://doi.org/10.4000/geomorphologie.10965, 2015.

Magnin, F., Josnin, J-Y., Ravanel, L., Pergaud, J., Pohl, B., Deline, P.: Modelling rock wall permafrost degradation in the Mont Blanc massif from the LIA to the end of the 21st century, The Cryosphere, 11: 1813-1834, https://doi.org/10.5194/tc11-1813-2017, 2017.

Mamot, P., Weber, S., Schröder, T., and Krautblatter, M.: A temperature- and stress-controlled failure criterion for ice-filled permafrost rock joints, The Cryosphere, 12: 3333-3353, https://doi.org/https://doi.org/10.5194/tc-12-3333-2018, 2018.

Matsuoka, N.: Mechanisms of rock breakdown by frost action - an experimental approach. Cold Regions Science and Technology, 17: 253-270, https://doi.org/10.1016/S0165-232X(05)80005-9, 1990.

630 Matsuoka, N.: Frost weathering and rockwall erosion in the eastern Swiss Alps: Long-term (1994-2006) observations, Geomorphology, https://doi.org/10.1016/j.geomorph.2007.11.013, 2008.

Matsuoka, N. and Murton, J.: Frost weathering: recent advances and future directions, Permafrost Periglac Process, 19:195210, https://doi.org/10.1002/ppp.620, 2008.

McColl, S. T. and Draebing, D.: Rock slope instability in the proglacial zone: State of the Art. In T. Heckmann \& D. Morche

635 (Eds.), Geomorphology of proglacial systems - Landform and sediment dynamics in recently deglaciated alpine landscapes, 119-141, Heidelberg: Springer, https://doi.org/10.1007/978-3-319-94184-4_8, 2019.

McDowell, G. and Koppes, M.: Robust adaptation research in high mountains: integrating the scientific, social, and ecological dimensions of glacio-hydrological change, Water 9, 739, https://doi.org/10.3390/w9100739, 2017.

McDowell, G., Stephenson, E., Ford, J.: Adaptation to climate change in glaciated mountain regions, Climatic Change, 126,

640 77-91. https://doi.org/10.1007/s10584-014-1215-z, 2019.

Mellor, M.: Strength and deformability of rocks at low temperature, CRREL Res. Rep. 294, 1971.

Mellor, M.: Mechanical properties of rocks at low temperatures, 2nd International Conference on Permafrost, Northamerican Contribution, Yakutsk, USSR, 334-344, 1973.

Mennessier, G., Carme, F., Bellière, J., Dhellemes, R., Antoine, P., Dabrowski, H., et al.: Notice explicative : Carte

645 Géologique de la France à 1: 50 000, Feuille ST-Gervais-les-Bains, 1977.

Moore, JR, Gischig, V, Katterbach, M, Loew, S.: Air circulation in deep fractures and the temperature field of an alpine rock slope, Earth Surf Process Land, 36:1985-1996, https://doi.org/10.1002/esp.2217, 2011.

Mourey, J. and Ravanel, L.: Measuring the attendance of access routes to high mountain in the Mont-Blanc massif using pyroelectric sensors, Collection EDYTEM SI Monitoring en milieux naturels, retours d'expériences en terrains difficiles, 263 $650-270$, https://doi.org/10.3406/edyte.2017.1394, 2017. 
Mourey, J., Moret, O., Descamps, P., Bozon, S.: Accidentology of the normal route up Mont Blanc between 1990 and 2017, Fondation Petzl, 20, https://www.petzl.com/fondation/projets/accidents-couloir-gouter?language=en, 2018.

Mourey, J., Marcuzzi, M., Ravanel, L., Pallandre, F.: Effects of climate change on high Alpine environments: evolution of mountaineering routes in the Mont Blanc massif (Western Alps) over half a century, Arctic, Antarctic and Alpine Research, 51(1): 176-189, https://doi.org/10.1080/15230430.2019.1612216, 2019.

Mourey, J., Perrin-Malterre, C., Ravanel, L.: Strategies used by French Alpine guides to adapt to the effects of climate change. Journal of outdoor recreation and tourism, 29, https://doi.org/10.1016/j.jort.2020.100278, 2020.

Paul, F., Rastner, P., Azzoni, R. S., Diolaiuti, G., Fugazza, D., Le Bris, R., Nemec, J., Rabatel, A., Ramusovic, M., Schwaizer, G., Smiraglia, C.: Glacier shrinkage in the Alps continues unabated as revealed by a new glacier inventory from Sentinel-2,

660 Earth Syst. Sci. Data, 12, 1805-1821, https://doi.org/10.5194/essd-12-1805-2020, 2020.

Pohl, B., Joly, D., Pergaud, J., Buoncristiani,J-F., Soare, P., Berger, A.: Huge decrease of frost frequency in the Mont-Blanc Massif under climate change, Scientific Reports, 9:4919, https://doi.org/10.1038/s41598-019-41398-5, 2019.

Pröbstl-Haider, U., Dabrowska, K., Haider, W.: Risk perception and preferences of mountain tourists in light of glacial retreat and permafrost degradation in the Austrian Alps, Journal of Outdoor Recreation and Tourism, 13: 66-78, 665 https://doi.org/10.1016/j.jort.2016.02.002, 2016.

Purdie, H. and Kerr, T.: Aoraki Mont Cook : Environmental change on an iconic mountaineering route, Mountain Research and Development, 38(4): 364-379, https://doi.org/10.1659/MRD-JOURNAL-D-18-00042.1, 2018.

Ravanel, L. and Deline, P.: Climate influence on rockfalls in high-Alpine steep rockwalls : The north side of the Aiguilles de Chamonix ( Mont Blanc massif) since the end of the 'Little Ice Age', The Holocene, 21(2): 357-365. https://doi.org/10.1177/0959683610374887, 2010.

Ravanel, L., Magnin, F., Deline, P.: Impacts of the 2003 and 2015 summer heatwaves on permafrost-affected rock-walls in the Mont Blanc massif, Science of the Total Environment, 609:132-143, https://doi.org/10.1016/j.scitotenv.2017.07.055, 2017.

675 Ridler, T. W. and Calvard, S.: Picture thresholding using an iterative selection method, IEEE trans syst Man Cybern, 8(8): 630-632, https://doi.org/10.1109/TSMC.1978.4310039, 1978.

Ritter, F., Fiebig, M., Muhar, A.: Impacts of Global Warming on Mountaineering: A Classification of Phenomena Affecting the Alpine Trail Network, Mountain Research and Development, 32:4-15, https://doi.org/10.1659/MRD-JOURNAL-D-11$\underline{00036.1}, 2011$.

680 Sass, O.: Rock moisture measurements: techniques, results, and implications for weathering, Earth Surf Process Land, 30:359374, https://doi.org/10.1002/esp.1214, 2005. 
https://doi.org/10.5194/nhess-2021-128

Preprint. Discussion started: 27 April 2021

(c) Author(s) 2021. CC BY 4.0 License.

Seto, M.: Freeze thaw cycles on rock surfaces below the timberline in a montane zone: field measurements in Kobugahara, Northern Ashio Mountains, Central Japan, Catena 82, 218-226, https://doi.org/10.1016/j.catena.2010.06.006, 2010.

685 Temme, A.J.A.M.: Using Climber's Guidebooks to Assess Rock Fall Patterns Over Large Spatial and Decadal Temporal Scales: An Example from the Swiss Alps, Geografiska Annaler: Series A, Physical Geography, 97(4): 793-807, https://doi.org/10.1111/geoa.12116, 2015.

Weber, S., Beutel, J., Faillettaz, J., Hasler, A., Krautblatter, M., Vieli, A.: Quantifying irreversible movement in steep, fractured bedrock permafrost on Matterhorn (CH), The Cryosphere, 11: 567-583, https://doi.org/10.5194/tc-11-567-2017, 2017.

690 Weber, S., Faillettaz, J., Meyer, M., Beutel, J., Vieli, A.: Acoustic and Microseismic Characterization in Steep Bedrock Permafrost on Matterhorn (CH), Journal of Geophysical Research: Earth Surface, 123: 1363-1385, https://doi.org/10.1029/2018JF004615, 2018.

Weber, S., Beutel, J., Da Forno, R., Geiger, A., Gruber, S., Gsell, T., et al.: A decade of detailed observations (2008-2018) in steep bedrock permafrost at the Matterhorn Hörnligrat (Zermatt, CH), Earth System Science Data, 11: 1203-1237, 695 https://doi.org/https://doi.org/10.5194/essd-11-1203-2019, 2019.

Wegmann, M., Gudmundsson, GH.: Thermally induced temporal strain variations in rock walls observed at subzero temperatures. In Advances in Cold-Region Thermal Engineering and Sciences, Hutter K,Wang Y, Beer H (eds.). Springer: Berlin, 511-518, 1999.

Westermann, S., Schuler, T.V., Gisnas, K., Etzelmüller, B.: Transient thermal modeling of permafrost conditions in Southern 700 Norway, Cryosphere, 7(2), 719-739, https://doi.org/10.5194/tc-7-719-2013, 2013. 